\title{
A review of picobiine mites (Acari: Syringophilidae: Picobiinae) parasitising African birds
}

\author{
Maciej Skoracki ${ }^{1}$ and Martin Hromada ${ }^{2,3}$ \\ ${ }^{1}$ Department of Animal Morphology, Faculty of Biology, Adam Mickiewicz University, Poznań, Poland; \\ ${ }^{2}$ Department of Ecology, Faculty of Humanities and Natural Sciences \& Centre of Excellence for Animal and Human Ecology, \\ University of Prešov, Prešov, Slovakia; \\ ${ }^{3}$ Institute of Zoology, Poznań University of Life Sciences, Poznań, Poland
}

\begin{abstract}
A fauna of quill mites of the subfamily Picobiinae (Acari: Syringophilidae) associated with African birds is revised. Two new monotypic genera are proposed, Gunabopicobia gen. n. for Picobia zumpti Lawrence, 1959 and Lawrencipicobia gen. n. for Picobia poicephali Skoracki et Dabert, 2002. These new genera differ from other genera of the subfamily by the following features: in females of Gunabopicobia, propodonotal setae $v i$ are situated anterior to the level of setae ve; the narrow lateral propodonotal shields bear bases of setae $v i, v e, s i$ and $s e$; the bases of setae $1 a-1 a$ are coalesced; the genital setae and the opisthosomal lobes are absent; the leg I with full set of solenidia and apodemes I are devoid of the thorn-like protuberances in the middle part. In females of Lawrencipicobia, the bases of setae $1 a-1 a$ are not coalesced; the propodonotal shield is entire; the genital setae are present; legs I are with full set of solenidia. Additionally, two new species belonging to Picobia Haller, 1878 are described, Picobia illadopsae sp. n. parasitising Illadopsis rufipennis (Sharpe) (Passeriformes: Pellorneidae) in Kenya and Picobia phoenicuri sp. n. infecting Phoenicurus moussieri (Olphe-Galliard) in Tunisia. The following species are redescribed, Columbiphilus alectoris (Fain, Bochkov et Mironov, 2000), Lawrencipicobia poicephali (Skoracki et Dabert, 2001) comb. n. and Picobia phoeniculi (Fain, Bochkov et Mironov, 2000). The key to the genera of the Picobiinae is provided.
\end{abstract}

Keywords: ectoparasites, taxonomy, quill mites, Lawrencipicobia, Gunabopicobia

Mites of the subfamily Picobiinae Johnston et Kethley, 1973, like other syringophilids (Acariformes: Syringophilidae) are permanent and highly specialized ectoparasites of birds inhabiting the feather quills, where they live and reproduce. These mites are mono- or oligoxenous parasites associated with birds of different orders throughout the world. At present, this subfamily includes 6 genera and 47 species, Calamincola Casto, 1977 (one species), Columbiphilus Kivganov et Sharafat, 1995 (4), Neopicobia Skoracki, 2011 (10), Picobia Haller, 1878 (26, including 3 species as incertae sedis); Pseudopicobia Skoracki, Scibek et Sikora, 2012 (3), and Rafapicobia Skoracki, 2011 (3) (see Table 1).

The picobiine mites parasitising African birds are still insufficiently explored. Nowadays, only 12 species belonging to 4 genera are known from African avian hosts (Table 2). Most of them (9 species) represent monoxenic parasites, whereas only two, Neopicobia zumpti (Lawrence, 1958) and Picobia oritis Skoracki, Antczak et Riegert, 2009 have been recorded from closely related hosts (from one genus), and only one, Picobia phoeniculi Fain, Bochkov et Mironov, 2000, from hosts belonging to two families of the same avian order (Table 2).

In this paper, we review all data on picobiines parasitising African birds and two new genera are proposed. Additionally, two new species belonging to the genus $P i$ cobia Haller, 1878 are described from Illadopsis rufipennis (Sharpe) (Passeriformes: Pellorneidae) in Kenya and Phoenicurus moussieri (Olphe-Galliard) in Tunisia, and three species are redescribed. The key to the genera of the Picobiinae is also provided.

\section{MATERIALS AND METHODS}

Specimens from the type-series of all available species have been examined. They were loaned from collections deposited in different museums and institutions (listed below). Material was examined under an Olympus BH-2 light microscope with differential interference contrast (DIC) optics. Drawings were made with the aid of a drawing attachment. All measurements are given in micrometres. Measurements (ranges) of paratypes are given in brackets following data on holotype. In the descriptions below, the idiosomal setation follows Grandjean (1939) as adapted for Prostigmata by Kethley (1990). The nomenclature of leg chaetotaxy follows that proposed by Grandjean (1944). 
Table 1. Quill mite genera of the subfamily Picobiinae Johnston et Kethley, 1973 and their host associations.

\begin{tabular}{|c|c|c|c|c|c|}
\hline Mite genus & $\begin{array}{l}\text { No. of } \\
\text { species }\end{array}$ & Host order & Host families & Distribution & Main references \\
\hline Calamincola Casto, 1977 & 1 & Cuculiformes & Cuculidae & North America & Casto 1977 \\
\hline \multirow[t]{3}{*}{$\begin{array}{l}\text { Columbiphilus Kivganov et } \\
\text { Sharafat, } 1995\end{array}$} & 2 & Galliformes & Phasianidae & $\begin{array}{l}\text { Africa, Asia, } \\
\text { Europe }\end{array}$ & $\begin{array}{l}\text { Fain et al. 2000, Skoracki 2011, } \\
\text { Skoracki and Sikora 2011, } \\
\text { Skoracki et al. } 2001\end{array}$ \\
\hline & 1 & Columbiformes & Columbidae & Asia & $\begin{array}{l}\text { Kivganov and Sharafat 1995, } \\
\text { Skoracki } 2011\end{array}$ \\
\hline & 1 & Pteroclidiformes & Pteroclididae & Africa & Skoracki and O'Connor 2010 \\
\hline Gunabopicobia gen. n. & 1 & Columbiformes & Columbidae & $\begin{array}{l}\text { Africa, } \\
\text { North America }\end{array}$ & $\begin{array}{l}\text { Lawrence } 1959 \text {, } \\
\text { Bochkov et al. } 2005 \text {, } \\
\text { present paper }\end{array}$ \\
\hline Lawrencipicobia gen. n. & 1 & Psittaciformes & Psittacidae & Africa & $\begin{array}{l}\text { Skoracki and Dabert 2002, } \\
\text { present paper }\end{array}$ \\
\hline \multirow[t]{2}{*}{ Neopicobia Skoracki, 2011} & 9 & Passeriformes & $\begin{array}{l}\text { Acanthizidae, Cardinallidae, Fringillidae, } \\
\text { Locustellidae, Meliphagidae, Motacilli- } \\
\text { dae, Prunellidae, Troglodytidae }\end{array}$ & $\begin{array}{l}\text { Europe, } \\
\text { North America, } \\
\text { Australia, Asia }\end{array}$ & $\begin{array}{l}\text { Skoracki and Magowski 2001, } \\
\text { Skoracki and Glowska 2008, } \\
\text { Skoracki et al. 2008, 2010, } \\
\text { Skoracki } 2011\end{array}$ \\
\hline & 1 & Psittaciformes & Psittacidae & Australia & Skoracki et al. 2008 \\
\hline \multirow[t]{5}{*}{ Picobia Haller, 1878} & 22 & Passeriformes & $\begin{array}{l}\text { Acrocephalidae, Aegithalidae, Alaudi- } \\
\text { dae, Cettidae, Corcoracidae, Corviidae, } \\
\text { Fringillidae, Hirundinidae, Leiothrichidae, } \\
\text { Muscicapidae, Nectarinidae, Panuridae, } \\
\text { Paradisaeidae, Pellorneidae, Ploceidae, } \\
\text { Pycnonotidae, Sturnidae, Sylviidae, } \\
\text { Troglodytidae }\end{array}$ & $\begin{array}{l}\text { Europe, Asia, } \\
\text { Australia, Africa }\end{array}$ & $\begin{array}{l}\text { Bochkov et al. 2000, } \\
\text { Skoracki and Kiljan 2002, } \\
\text { Skoracki and Hebda 2004, } \\
\text { Skoracki et al. 2004, 2008, 2009, } \\
\text { Glowska et al. 2007, 2012, } \\
\text { Skoracki and Glowska 2008, } \\
\text { Glowska and Skoracki 2011, } \\
\text { Skoracki 2011, } \\
\text { Sikora et al. 2012, } \\
\text { present paper }\end{array}$ \\
\hline & $1 *$ & Psittaciformes & Psittacidae & South America & Fain et al. 2000 \\
\hline & $1 *$ & Charadriiformes & Laridae & North America & Skoracki et al. 2010 \\
\hline & 2 & Piciformes & Picidae & $\begin{array}{l}\text { Europe, } \\
\text { North America }\end{array}$ & $\begin{array}{l}\text { Skoracki et al. 2010, } \\
\text { Skoracki } 2011\end{array}$ \\
\hline & 1 & Coraciiformes & Phoeniculidae, Upupidae & Africa & $\begin{array}{l}\text { Fain et al. } 2000 \\
\text { present paper }\end{array}$ \\
\hline $\begin{array}{l}\text { Pseudopicobia Skoracki, } \\
\text { Scibek et Sikora, } 2012\end{array}$ & 3 & Piciformes & Bucconidae & South America & Skoracki et al. 2012a \\
\hline Rafapicobia Skoracki, 2011 & 3 & Passeriformes & Funariidae, Mimidae, Muscicapidae & $\begin{array}{l}\text { Europe, } \\
\text { North America, } \\
\text { South America }\end{array}$ & $\begin{array}{l}\text { Sikora et al. 2011, } \\
\text { Skoracki 2011, } \\
\text { Skoracki and Solarczyk } 2012\end{array}$ \\
\hline
\end{tabular}

* incertae sedis species.

The morphological terminology follows Skoracki (2011). The scientific names of the birds follow Clements et al. (2012). Specimen depositories and reference numbers are cited using the following abbreviations: AMU - Adam Mickiewicz University, Department of Animal Morphology, Poznan, Poland; IPCAS - Institute of Parasitology, Biology Centre of the Academy of Sciences of the Czech Republic, České Budějovice, Czech Republic; NMSA - Natal Museum, Pietermaritzburg, South Africa; RBINS - Royal Belgian Institute of Natural Science, Brussels, Belgium; RMCA - Royal Museum for Central Africa, Tervuren, Belgium; UMICH - Museum of Zoology, University of Michigan, USA; ZISP - Zoological Institute, Russian Academy of Sciences, St. Petersburg, Russia; ZSM - Bavarian State Collection of Zoology, Munich, Germany.

\section{RESULTS}

Family Syringophilidae Lavoipierre, 1953

Subfamily Picobiinae Johnston et Kethley, 1973

Genus Columbiphilus Kivganov et Sharafat, 1995

Columbiphilus - Kivganov and Sharafat 1995: 82; Skoracki 2011: 373. Picobia - Bochkov and Mironov 1998: 15.
Type species: Columbiphilus khushalkhani Kivganov et Sharafat, 1995 by original designation.

\section{Diagnosis}

Female. Gnathosoma. Hypostomal apex rounded or truncate. Peritremes with clearly visible chambers in lateral and medial branches. Movable cheliceral digits edentate on distal tip. Idiosoma. Propodonotal setae smooth or beaded. Propodonotal setae arranged $2-2-2$ or $2-1-1-2$, setae vi situated anterior to level of setae ve. Propodonotal shield divided into two lateral shields bearing bases of setae vi, ve, si and se, unpaired medial shield present or absent. Hysteronotal and pygidial shields absent. Alveoles of setae $1 a-1 a$ coalesced. Pseudanal setal series represented by two pairs. Genital setal series with one pair. Aggenital series with three pairs of setae. Aggenital and genital plates absent. Genital and opisthosomal lobes absent. Legs. Apodemes of legs I divergent without thornlike protuberances in middle part. Legs with full set of solenidia. Physogastric female campanulliform in outline.

Male. Features as in females except: propodonotal shield not divided, long-sleeved shirt-like; hysteronotal and pygidial shields present; each of genital and aggeni- 
Table 2. Mites of the subfamily Picobiinae Johnston et Kethley, 1973 parasitising African birds.

\begin{tabular}{|c|c|c|c|c|c|}
\hline Mite species & Host species & Host family & Host order & Distribution & References \\
\hline \multicolumn{6}{|l|}{$\begin{array}{l}\text { Columbiphilus Kivganov et } \\
\text { Sharafat, } 1995\end{array}$} \\
\hline $\begin{array}{l}\text { C. alectoris (Fain, Bochkov } \\
\text { et Mironov, 2000) }\end{array}$ & Alectoris sp. & Phasianidae & Galliformes & Rwanda & $\begin{array}{l}\text { Fain et al. 2000, } \\
\text { Skoracki } 2011, \\
\text { present paper }\end{array}$ \\
\hline \multirow[t]{2}{*}{$\begin{array}{l}\text { C. pteroclesi (Skoracki et } \\
\text { O'Connor, 2010) }\end{array}$} & Pterocles senegallus (Linnaeus) & Pteroclididae & Pteroclidiformes & Egypt & $\begin{array}{l}\text { Skoracki and O’Connor 2010, } \\
\text { Skoracki } 2011\end{array}$ \\
\hline & Pterocles coronatus Lichtenstein & Pteroclididae & Pteroclidiformes & Egypt & $\begin{array}{l}\text { Skoracki and O'Connor 2010, } \\
\text { Skoracki } 2011\end{array}$ \\
\hline \multicolumn{6}{|l|}{ Gunabopicobia gen. n. } \\
\hline \multirow[t]{2}{*}{$\begin{array}{l}\text { G. zumpti (Lawrence, 1958) } \\
\text { comb. n. }\end{array}$} & Streptopelia capicola (Sundevall) & Columbidae & Columbiformes & South Africa & $\begin{array}{l}\text { Lawrence } 1959 \\
\text { Kethley } 1970\end{array}$ \\
\hline & Streptopelia senegalensis (Linnaeus) & Columbidae & Columbiformes & South Africa & $\begin{array}{l}\text { Skoracki and Dabert 2002, } \\
\text { present paper }\end{array}$ \\
\hline \multicolumn{6}{|l|}{ Lawrencipicobia gen. n. } \\
\hline $\begin{array}{l}\text { L. poicephali (Skoracki et } \\
\text { Dabert, 2002) comb. n. }\end{array}$ & Poicephalus senegalus versteri Finsch & Psittacidae & Psittaciformes & Cameroon & $\begin{array}{l}\text { Skoracki and Dabert 2002, } \\
\text { present paper }\end{array}$ \\
\hline \multicolumn{6}{|l|}{ Picobia Haller, 1878} \\
\hline $\begin{array}{l}\text { P. cichladusa Skoracki, } \\
\text { Solarczyk et Sikora, } 2012\end{array}$ & Cichladusa arquata Peters & Muscicapidae & Passeriformes & Tanzania & Skoracki et al. 2012b \\
\hline $\begin{array}{l}\text { P. dinemellia Glowska et } \\
\text { Skoracki, } 2011\end{array}$ & Dinemellia dinemelli (Ruppell) & Ploceidae & Passeriformes & Tanzania & Glowska and Skoracki 2011 \\
\hline $\begin{array}{l}\text { P. echo Skoracki, Solarczyk } \\
\text { et Sikora, } 2012\end{array}$ & Cossypha heuglini Hartlaub & Muscicapidae & Passeriformes & D.R. Congo & Skoracki et al. 2012b \\
\hline P. illadopsae sp. n. & Illadopsis rufipennis (Sharpe) & Pellorneidae & Passeriformes & Kenya & present paper \\
\hline $\begin{array}{l}\text { P. myrmecocichla Skoracki, } \\
\text { Solarczyk et Sikora, } 2012\end{array}$ & Myrmecocichla arnotti (Tristram) & Muscicapidae & Passeriformes & Tanzania & Skoracki et al. 2012b \\
\hline \multicolumn{2}{|c|}{$\begin{array}{l}\text { P. oritis Skoracki, Antczak et Cyanomitra oritis (Reichenov) } \\
\text { Riegert, } 2009\end{array}$} & Nectariniidae & Passeriformes & Cameroon & Skoracki et al. 2009 \\
\hline \multirow{3}{*}{$\begin{array}{l}\text { P. phoeniculi Fain, Bochkov } \\
\text { et Mironov, } 2000\end{array}$} & Cyanomitra olivacea (Smith) & Nectariniidae & Passeriformes & Kenya & Skoracki et al. 2011 \\
\hline & Phoeniculus purpureus (Miller) & Phoeniculidae & Coraciiformes & Rwanda & $\begin{array}{l}\text { Fain et al. } 2000 \text {, } \\
\text { present paper }\end{array}$ \\
\hline & Upupa epops africana Bechstein & Upupidae & Coraciiformes & Tanzania & present paper \\
\hline P. phoenicuri sp. n. & $\begin{array}{l}\text { Phoenicurus moussieri (Olphe- } \\
\text { Galliard) }\end{array}$ & Muscicapidae & Passeriformes & Tunisia & present paper \\
\hline
\end{tabular}

tal setal series represented by two pairs; aggenital plate present; apodemes I parallel.

Habitat, host range and distribution. Members of this genus occupy quills of body feathers of birds from three orders, Columbiiformes (Columbidae), Galliformes (Phasianidae) and Pteroclidiformes (Pteroclididae), and they were recorded from the Palaearctic and Ethiopian regions (Skoracki 2011). In Africa, picobiines of this genus are associated with galliform and pteroclidiform birds.

Species included. Among four described species in this genus, the African fauna comprises two of them, C. alectoris and C. pteroclesi.

Columbiphilus alectoris (Fain, Bochkov et Mironov, 2000)

Figs. 1, 2

Picobia alectoris - Fain et al. 2000: 65, figs. 103-109; Skoracki et al. 2004: 164. Columbiphilus alectoris - Skoracki 2011: 374.

Picobia alectoris was described by Fain et al. (2000) based on female found on unidentified chukar species, Alectoris Kaup in Rwanda. Recently, Skoracki (2011) has moved this species to Columbiphilus. Below we give a redescription of this species based on the type material housed in the RBINS.

\section{Redescription}

Female (holotype). Total body length 915. Gnathoso$m a$. Hypostomal apex truncate. Infracapitulum apunctate. Each medial branch with seven chambers, each lateral branch with ten chambers, borders between these chambers clearly visible. Stylophore 290 long. Idiosoma. Propodonotal shield divided into two lateral shields, punctate near bases of setae ve and si, and large apunctate medial shield. Propodonotal setae vi, ve and si lightly beaded. Length ratio of setae $v i: v e: s i-1: 1.3: 1.7$. Setae $c 1$ and se located at same transverse level. Setae $d 1$ situated equidistant to setae $d 2$ and $e 2$. Setae $f 17.4$ times longer than $f 2$. Setae $h 218$ times longer than $h 1$. Aggenital setae $a g 1$ situated anterior to level of setae $a g 2$, bases of both pair of setae situated in longitudinal row. Length ratio of setae ag1 : ag2 : ag3 - $1: 1: 1.3$. Setae $p s 2$ slightly (1.2 times) longer than setae $p s 1$ and $g 1$. Setae $g l$ hair-like. Legs. Antaxial and paraxial members of claw pair of legs III and IV unequal in size and shape. Setae $t c$ ' $I I I-I V$ slightly (1.3 times) longer than $t c$ ' $I I I-I V$. Setae $3 c$ about 4.6 times longer than $3 b$. Setae $4 c 6$ times longer than $4 b$. Coxal fields I-IV well developed, apunctate. Lengths of setae: $v i$ 110, ve 140, si 185, se 330, c1 390, c2 315, d1 345, d2 330, e2 285,f1 445,f2 60, h1 20, h2 360, ps1 40, ps 2 50, g1 40, 


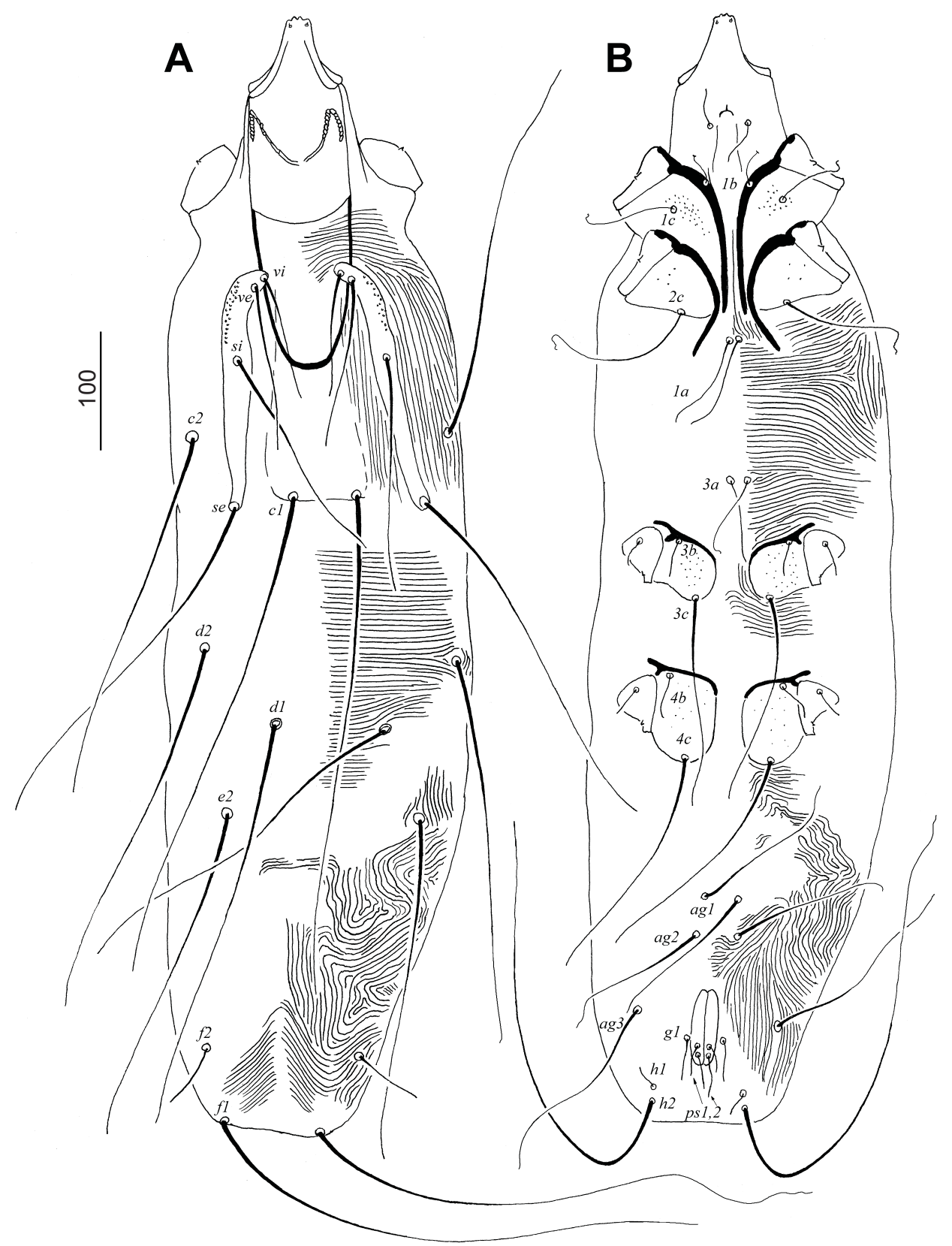

Fig. 1. Columbiphilus alectoris (Fain, Bochkov et Mironov, 2000), female from Alectoris sp. A - dorsal view; B - ventral view.

ag1 140, ag2 140,ag3 180, l'RIII and l'RIV 35, tc'III-IV 55, tc" III-IV 70, 3b 35, 3c 160, 4c 215.

Male. Unknown.

Type material examined: Female holotype from Alectoris sp. (Galliformes: Phasianidae); Rwanda, October 1955, coll. A. Fain. Type material is deposited in the RBINS (Reg. No. RBINS 187373).

Columbiphilus pteroclesi (Skoracki et O'Connor, 2010)

Picobia pteroclesi - Skoracki and O’Connor 2010: 27, figs. 78-88. Columbiphilus pteroclesi-Skoracki 2011: 379.

This species was originally described in the genus $P i$ cobia based on material found on two sandgrouse species in Egypt, Pterocles senegallus (Linnaeus) and P. coronatus Lichtenstein (Pteroclidiformes, Pteroclididae). Later on, Skoracki (2011) moved this species to the genus Columbiphilus.

\section{Diagnosis}

Female. Hypostomal apex rounded, with shoulders, flanked by pair of small hypostomal teeth. Each medial branch of peritremes with 6-7 chambers, each lateral branch with 10-11 chambers. Propodonotal shield divided into two lateral and unpaired medial shields. Length ratios of setae $v i: v e: s i-1: 1.6-1.8: 1.9-2.2 ; f 1: f 2-$ 1: 1.6; ag1 :ag2 : ag3-2: $1: 2$. Setae vi, ve and si smooth. 

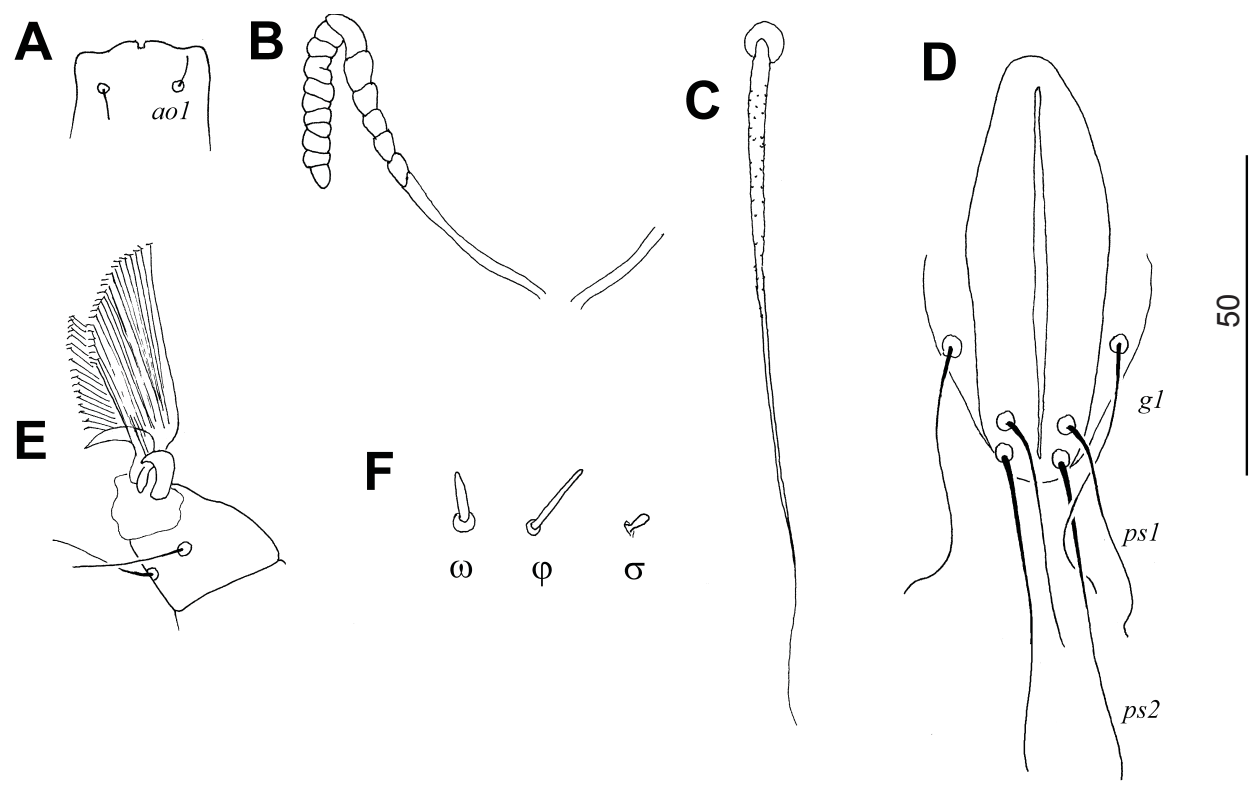

Fig. 2. Columbiphilus alectoris (Fain, Bochkov et Mironov, 2000), female from Alectoris sp. A - hypostomal apex; B - peritreme; $\mathbf{C}$ - propodonotal seta ve; $\mathbf{D}$ - vulva; $\mathbf{E}$ - tarsus III in ventrolateral view; $\mathbf{F}$ - solenidia of leg I.

Antaxial and paraxial members of claw pair of legs III and IV equal in size and shape. Physogastric form unknown.

Male. Hypostomal apex rounded, with shoulders, without hypostomal teeth. Each medial branch of peritremes with 6-7 chambers, each lateral branch with 1011 chambers. Propodonotal shield divided into two lateral and unpaired medial shields. Length ratios of setae $v i$ : ve : si-1 : 1.7-2 : 2-2.2; e2 : d1 : d2 - $1: 2.8-3: 2.2-2.9$; $f 2:$ h2 $1: 7-8$; agl : ag2 $1.2: 1$. Hysteronotal shield entire. Aggenital plate entire, concave on posterior margin.

Type material examined: Female holotype and ten female and three male paratypes from spotted sandgrouse Pterocles senegallus (Pteroclidiformes: Pteroclididae); Egypt, Red Sea Governate, Wadi el Metuli, 45 km. E, 31 January 1983, coll. H. Touharny and S.M. Goodman. Type material is deposited in the UMICH (BMOC 830307-33), AMU (Reg. No. AMU-SYR.424) and ZISP (Reg. No. ZISP-AVB 011-2908-049).

Additional material examined: 24 females, one male, and two tritonymphs from crowned sandgrouse Pterocles coronatus (Pteroclididae); Egypt, Red Sea Governate, Bir Beida, 6.5 km. West Quseir, 4 February 1983, coll. S.M. Goodman and I. Helmy. Mite material is deposited in the UMICH (BMOC 83-0307-43), AMU (Reg. No. AMUSYR.425) and ZISP (Reg. No. ZISP-AVB011-2908-050).

\section{Genus Gunabopicobia gen. n.}

Type and only species: Picobia zumpti Lawrence, 1959

\section{Diagnosis}

Female. Gnathosoma. Hypostomal apex ornamented by pair of shoulders. Peritremes M-shaped with clearly visible chambers in lateral and medial branches. Mov- able cheliceral digits edentate on distal tip. Stylophore rounded posteriorly. Idiosoma. Dorsal propodonotal setae smooth. Six pairs of propodonotal setae present, arranged 2-1-1-2, setae $v i$ situated anterior to level of setae ve. Propodonotal shield divided into two narrow shields bearing bases of setae $v i$, ve, si and se, and large medial shield. Hysteronotal and pygidial shields absent. Setae $d 1$ situated slightly closer to $e 2$ than to $d 2$. Alveoles of setae $1 a-1 a$ coalesced. Pseudanal setal series represented by two pairs. Genital setae absent. Aggenital series with three pairs of setae. Aggenital and genital plates absent. Genital and opisthosomal lobes absent. Legs. Apodemes I slightly divergent without thorn-like protuberances in middle part. Legs with full complement of solenidia. Physogastric form unknown.

Male. Features as in females except: hypostomal apex truncate; hysteronotal shield not fused to pygidial shield; genital and aggenital series represented by two pairs of setae, each; aggenital plate present.

Etymology. The generic epithet 'Gunabopicobia' derives from the African god, Gunab, the creator of a rainbow.

Differential diagnosis. Gunabopicobia gen. n. is morphologically similar to Picobia Haller, 1878. In females of both genera, each branch of peritremes has clearly visible chambers, the movable cheliceral digit is edentate on distal tip, the alveoles of setae $1 a-1 a$ are coalesced and the legs I are with full complement of solenidia. The new genus differs from Picobia by the features as follows: in females of Gunabopicobia, propodonotal setae vi are situated anterior to level of setae ve; narrow lateral propodonotal shields bearing bases of setae vi, ve, si and se; genital setae are absent; and apodemes I are devoid of 


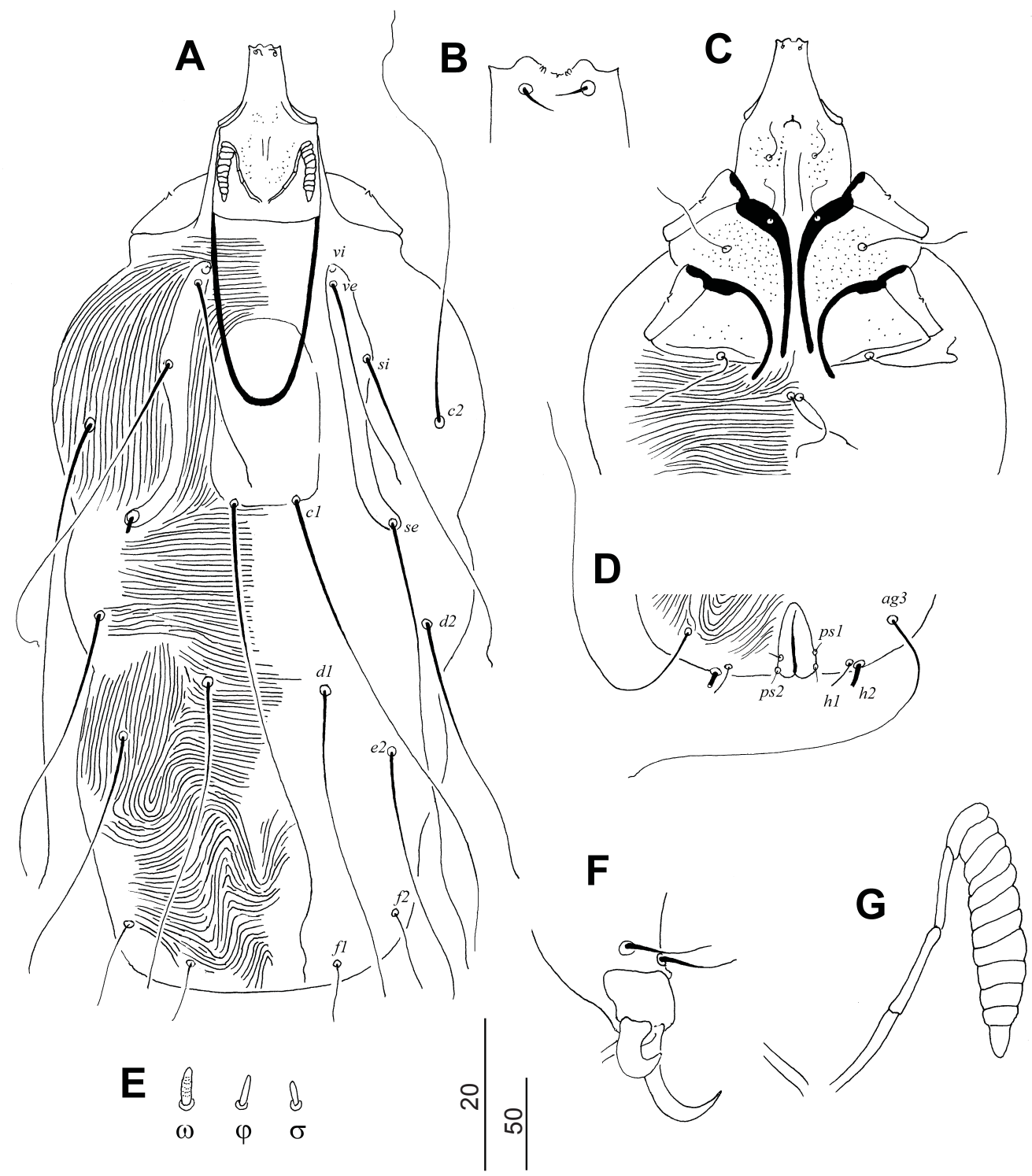

Fig. 3. Gunabopicobia zumpti (Lawrence, 1959), female from Streptopelia senegalensis. A - dorsal view; B - hypostomal apex; $\mathbf{C}$ - anterior part of body in ventral view; D - opisthosoma in ventral view; $\mathbf{E}$ - solenidia of leg I; F - tarsus III; $\mathbf{G}$ - peritreme. Scale bars: $\mathrm{A}, \mathrm{C}, \mathrm{D}=50 \mu \mathrm{m} ; \mathrm{B}, \mathrm{E}-\mathrm{G}=20 \mu \mathrm{m}$.

thorn-like protuberances in the middle part. In females of Picobia, propodonotal setae vi and ve are situated in the same transverse level; narrow lateral propodonotal shields bearing bases of setae ve, si and se; genital series represented by one pair of setae; and apodemes I are with thorn-like protuberances in the middle part.

Habitat, host range and distribution. Members of this genus occupy quills of body feathers of columbiform birds in the Ethiopian and Nearctic regions (Table 1).

Species included. Monotypic genus.

\section{Gunabopicobia zumpti}

(Lawrence, 1959) comb. n.

Fig. 3

Syringophilus zumpti - Lawrence 1959: 425, fig. 5. Picobia zumpti, Kethley 1970: 65, fig. 37; Skoracki and Dabert
2002: 144; Skoracki et al. 2004: 171; Bochkov et al. 2005: 122, figs. 1-3. Neopicobia zumpti - Skoracki 2011: 384.

This species was originally described based on a female collected on ring-necked dove Streptopelia capicola (Sundevall) in South Africa (Lawrence 1959). In 1970, Kethley re-examined its holotype deposited in the Natal Museum (South Africa) and placed this species into the genus Picobia. He also depicted the holotype but without any redescription. Later on, Skoracki and Dabert (2002) recorded this species based on female material from another dove species Streptopelia senegalensis (Linnaeus) in South Africa. In 2005, Bochkov et al. redescribed and figured this species based on female and male materials from rock pigeon Columba livia Gmelin in the United States (Bochkov et al. 2005). 


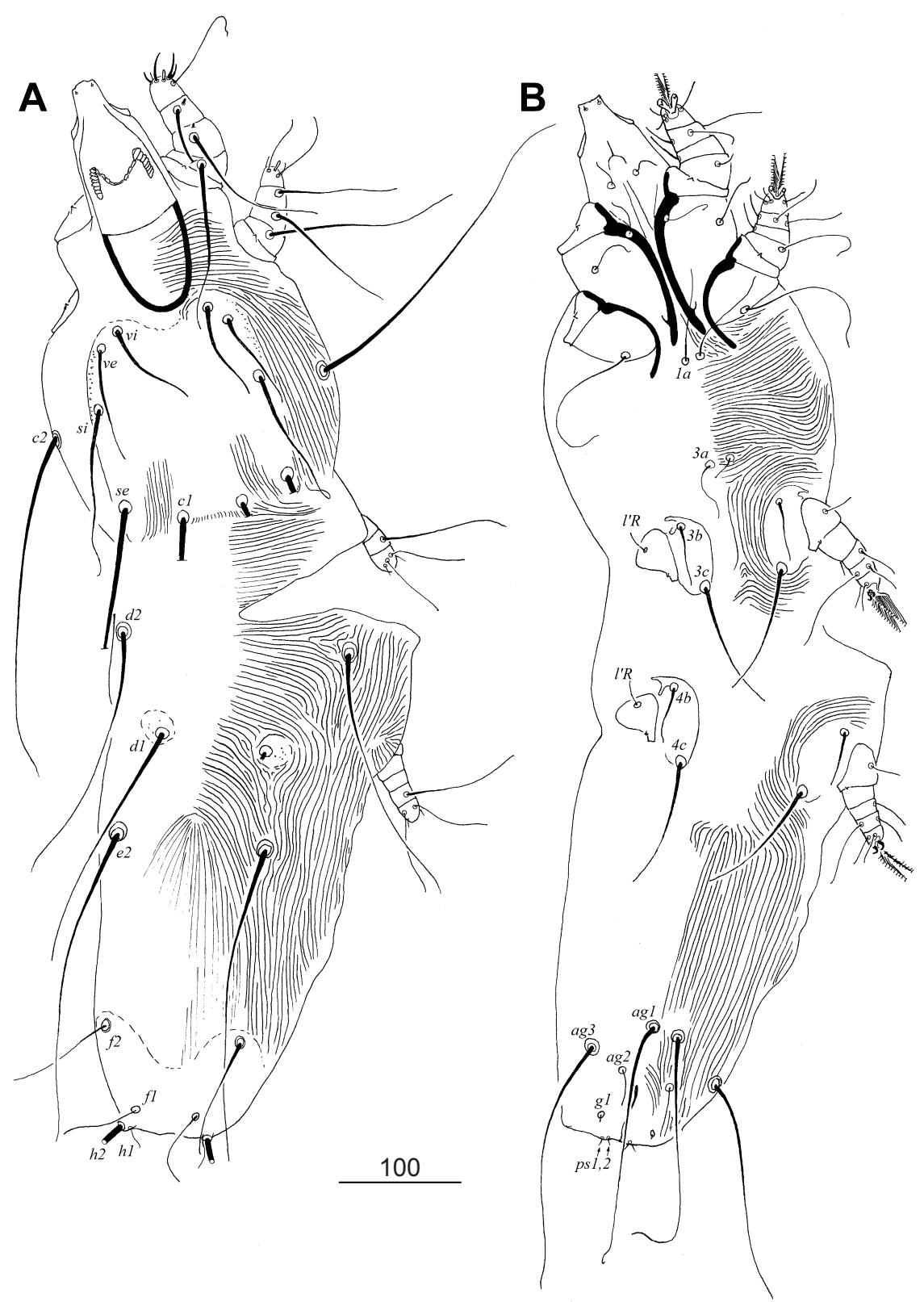

Fig. 4. Lawrencipicobia poicephali (Skoracki et Dabert, 2002), female from Poicephalus senegalus versteri. A - dorsal view; B - ventral view.

\section{Diagnosis}

Female. Hypostomal apex truncate, with shoulders without hypostomal teeth. Each medial branch of peritremes with 2-3 chambers, each lateral branch with 10-11 chambers. Propodonotal shield divided into two lateral and unpaired medial shields. Length ratios of setae $v i$ : ve : si-1 : 2-2.2 : 3.2-3.8; f1:f2-1: 1.5-2; ag1 : ag2 : ag3 $-1: 1: 3$. Setae $v i$, ve and si lightly beaded or smooth. Antaxial and paraxial members of claw pair of legs III and IV unequal in size and shape.

Male. Hypostomal apex truncate, without hypostomal teeth. Each medial branch of peritremes with 2-3 chambers, each lateral branch with 10-11 chambers. Propodo- notal shield divided into two lateral and unpaired medial shields. Length ratio of setae $v i: v e: s i-1: 2.7: 3.9 ;$; 2 $: d 1: d 2-1: 2: 4 ; f 2: h 2-1: 12.5 ;$ agl : ag2 - 1.2: 1 . Hysteronotal shield entire. Aggenital plate entire.

Type material (not examined): Female holotype from ring-necked dove Streptopelia capicola (Columbiformes: Columbidae); South Africa, Cape Province, Colesberg. Holotype is deposited in the NMSA.

Additional material examined: Four females from laughing dove Streptopelia senegalensis (Columbiformes: Columbidae); South Africa, Brakkloof, October 1963, collector unknown. Mite material is deposited in the RMCA (Reg. No. RMCA 188.546). 

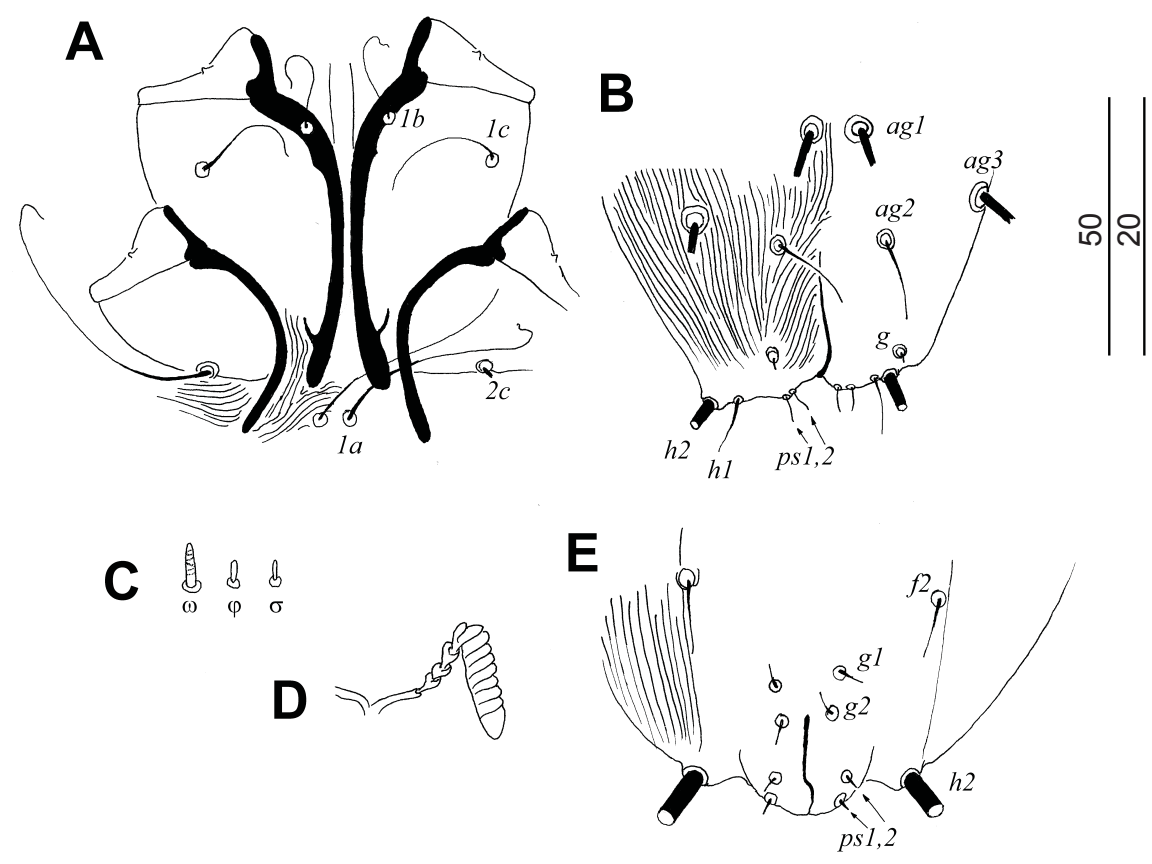

Fig. 5. Lawrencipicobia poicephali (Skoracki et Dabert, 2002) from Poicephalus senegalus versteri. Female (A-D). A - apodemes I and II; B - opisthosoma in ventral view; $\mathbf{C}$ - solenidia of leg I; D - peritreme. Male (E) from the same host species. $\mathbf{E}$ - opisthosoma in dorsal view. Scale bars: A, B, E $=50 \mu \mathrm{m} ; \mathrm{C}, \mathrm{D}=20 \mu \mathrm{m}$.

Comparative material: Two females and one male from rock pigeon Columba livia (Columbiformes: Columbidae); United States, Illinois, Ford Co., near Paxton, July 1999, coll. D. Clayton and B. Moyer. Mite material is deposited in the ZISP (Reg. No. ZISP-AVB011-2908-048).

\section{Genus: Lawrencipicobia gen. n.}

Type species: Picobia poicephali Skoracki et Dabert, 2002.

\section{Diagnosis}

Female. Gnathosoma. Hypostomal apex flat, without ornamentation. Peritremes M-shaped with clearly visible chambers in lateral and medial branches. Movable cheliceral digits edentate on distal tip. Stylophore rounded posteriorly. Idiosoma. Six pairs of propodonotal setae present, arranged 2-1-1-2, setae vi situated anterior to level of setae ve. Propodonotal shield entire, bearing bases of setae vi, ve, si, $c 1$ and se. Hysteronotal shield variable. Setae $d 1$ situated slightly closer to $e 2$ than to $d 2$. Pygidial shield present. Alveoles of setae $1 a-1 a$ not coalesced. Pseudanal series represented by two pairs of setae. Genital series represent by one pair of minute setae. Aggenital setal series with three pairs. Aggenital and genital plates absent. Genital and opisthosomal lobes absent. Legs. Apodemes I slightly divergent with small thorn-like protuberances in middle part. Legs with full complement of solenidia. Physogastric form unknown.

Male. Features as in females except: hypostomal apex slightly tapering; hysteronotal shield present, not fused to pygidial shield; genital and aggenital setal series represented by two pairs, each; aggenital plate variable.
Etymology. The generic epithet refers to the prominent acarologist, Dr. R.F. Lawrence, from Natal Museum, Pietermaritzburg, South Africa.

Differential diagnosis. This new genus is morphologically similar to Rafapicobia Skoracki, 2011. In females of both genera, the peritremes are M-shaped and have clearly visible chambers in the lateral and medial branches; dorsal setae are beaded; propodonotal setae are arranged $2-1-1-2$, and setae $v i$ are situated anterior to level of setae ve; the pygidial shield is present; alveoles of setae $1 a-1 a$ are not coalesced; the pseudanal series is represented by two pairs of setae; the genital series is represented by one pair of minute setae; the genital plate and genital lobes are absent. Lawrencipicobia gen. n. differs from Rafapicobia by the following characters: in females of Lawrencipicobia, the apodemes I are with thorn-like protuberances in middle part; legs I are with full complement of solenidia. In females of Rafapicobia, apodemes I are without thorn-like protuberances in middle part; legs I are without solenidia phi on tibiae I.

Host range and distribution. Mites of this genus occupy quills of body feathers of parrots and are known only from the Ethiopian region.

Species included. Monotypic genus.

\section{Lawrencipicobia poicephali}

(Skoracki et Dabert, 2002) comb. n.

Figs. 4-6

Picobia poicephali - Skoracki and Dabert 2002: 143, figs. 16-24; Skoracki et al. 2004: 17; Skoracki 2011: 329, as incertae sedis. 

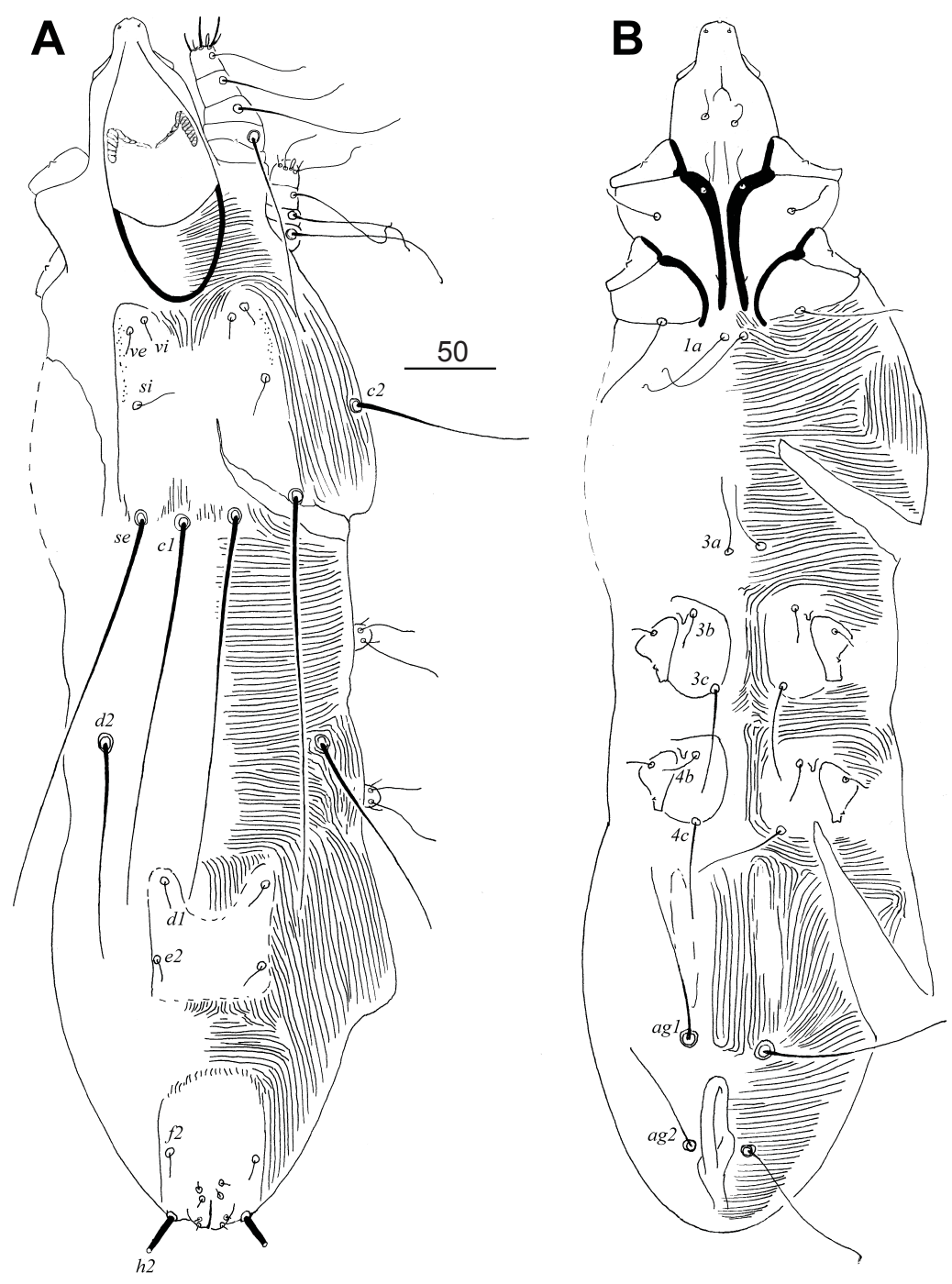

Fig. 6. Lawrencipicobia poicephali (Skoracki et Dabert, 2002), male from Poicephalus senegalus versteri. A - dorsal view; B - ventral view.

This species was originally described as Picobia poicephali Skoracki et Dabert, 2002 based on material collected from a subspecies of Senegal parrot, Poicephalus senegalus versteri Finsch (Psittaciformes, Psittacidae) in Cameroon. In 2011, Skoracki included this species into incertae sedis species group. Below, we give a redescription of this species based on type material housed in the RMCA.

\section{Redescription}

Female (holotype). Total body length 885. Gnathosoma. Hypostomal apex flat. Each medial branch of peritremes with 5-7 chambers, each lateral branch with 8-10 chambers. Stylophore 205 long. Idiosoma. Propodonotal shield entire, punctate near setal bases ve and si. Length ratio of setae $v i: v e-1: 1.3$. Setae se situated slightly anterior to level of setae $c 1$. All idiosomal setae except terminal setae $(d 4, d 5,14$ and 15$)$ beaded. Two small hysteronotal shields around bases of setae $d l$ present. Pygid- ial shield with indistinct anterior margin, apunctate, bearing bases of setae $f 1$ and $f 2$. Setae $g l$ short and thin. Two pairs of short pseudanal setae situated terminally. Aggenital setae $a g 1$ situated anterior to $a g 2$. Setae $a g 1$ and $a g 3$ subequal in length, both 5.5 times longer than ag2. Legs. All coxal fields well sclerotized, apunctate. Apodemes I weakly divergent, not fused to apodemes II; apodemes III and IV invisible. Dorsal and lateral setae of legs I and II beaded, remaining setae smooth. Antaxial and paraxial members of claw pair of legs III and IV equal in size and shape. Tarsal setae $t c$ ' and $t c$ " of legs III and IV subequal in length. Lengths of setae: vi 85, ve 110, si 140, d2 255, $h 2480, h 120, d 1210, f 2115, f 160, g 1$ 10, ps 1 and $p s 2$ 10, l'RIII 30, l'RIV 25, ag1 220, ag2 40, ag3 220, $3 b 45$.

Male (one paratype). Total body length 680. Gnathosoma. Hypostomal apex truncate. Each medial branch of peritremes with five chambers, each lateral branch with nine chambers. Stylophore 160, long. Idiosoma: Propodonotal shield entire, with concave anterior margin, punc- 
tate near bases of setae ve and si. Setae si twice as long as $v i$ and $v e$. Hysteronotal shield deeply concave on anterior margin, bearing bases of setae $d 1$ and $e 2$. Setae $d 28.7$ times longer than $d 1$ and $e 2$. Apunctate pygidial shield bearing basses of setae $f 2$ and $h 2$. Two narrow aggenital plates situated above bases of aggenital setae agl. Setae ag1 1.4 times longer than ag2. All idiosomal setae smooth. Legs. All coxal fields well sclerotized, apunctate. Dorsal and lateral setae of legs I and II beaded, remaining setae smooth. Tarsal setae $t c$ ' and $t c$ " of legs III and IV subequal in length. Setae $3 c$ about three times longer than 3b. Length of setae: vi 10, ve 10, si 20, c2 > 105, se 230, d2 130, e2 15, c1 230, d1 15, f2 15, agl 105, ag2 75, l'RIV $15,3 b 20,3 c 65$.

Type material examined: Female holotype and one male paratype from a subspecies of Senegal parrot Poicephalus senegalus versteri (Psittaciformes: Psittacidae); Cameroon, Galim, 21 August 1971, coll. F. Puylaert. Type material is deposited in the RMCA (Reg. No. RMCA 145.441).

\section{Genus: Picobia Haller, 1878}

Type species: Picobia heeri Haller, 1878

\section{Diagnosis}

Female. Gnathosoma. Hypostomal apex variable. Peritremes with clearly visible chambers in lateral and medial branches. Movable cheliceral digits edentate on distal tip. Idiosoma. Propodonotal setae arranged 2-2-2 or 2-1-1-2, setae $v i$ and ve situated at same transverse level. Propodonotal shield divided into two narrow shields bearing bases of setae ve, si and se, unpaired shield between these shields present or absent. Hysteronotal shield absent. Pygidial shield present or absent. Bases of setae $1 a-1 a$ coalesced. Pseudanal series represented by two pairs of setae. Genital setal series with one pair. Aggenital series with three pairs of setae. Aggenital plate absent. Genital plate present or absent. Genital lobes present or absent. Opisthosomal lobes absent. Legs. Apodemes parallel with thorn-like protuberances in middle part. Legs with full complement of solenidia. Physogastric form wormshaped outline.

Male. Features as in females except: hysteronotal and pygidial shields present, genital and aggenital setal series represent by two pairs, each; aggenital plate present.

Habitat, host range and distribution. Mites of this genus occupy quills of body feathers and are associated with birds from five orders, Charadriiformes, Coraciiformes, Passeriformes, Piciformes and Psittaciformes (Table 1). They are known from all zoogeographical regions except Antarctica (Skoracki 2011). In Africa, these mites were found on passeriform and coraciiform birds (listed in Table 2).

Species included. This genus includes 25 species (Skoracki et al. 2012c) and African fauna comprises seven of them: P. cichladusa, P. dinemellia, P. echo, P. myrmecocichla, $P$. oritis and $P$. phoeniculi. In addition, two new species are described below.

Picobia cichladusa Skoracki, Solarczyk et Sikora, 2012

Picobia cichladusa - Skoracki et al. 2012: 124, figs. 1-9.

This species has recently been described based on material found on muscicapid host species, Cichladusa arquata Peters (Passeriformes: Muscicapidae) in Tanzania. No other data are available since the original description.

\section{Diagnosis}

Female. Hypostomal apex rounded, without shoulders. Each medial branch of peritremes with 3-4 chambers, each lateral branch with seven chambers. Movable cheliceral digit edentate in posterior part. Podomers of palps densely punctate. Propodonotal shield divided into two narrow lateral and single oval median shields. Length ratios of setae $v i: v e: s i-1.3: 1: 1.3 ; f 1: f 2: h 1-1: 1.4$ : 1.4-1.5; ag1 : ag2 : ag3 - $1.3: 1: 2$. Setae vi, ve and si lightly beaded. Pygidial shield entire. Aggenital setae ag1 situated anterior to level of setae ag2. Genital plate present. Genital setae filiform, situated on genital lobes. Antaxial and paraxial members of claw pair of legs III and IV equal in size and shape.

Male. Hypostomal apex rounded. Each medial branch of peritremes with three chambers, each lateral branch with 7-8 chambers. Propodonotal shield divided into two narrow lateral and unpaired oval shields. Length ratios of setae $v i: v e: s i-1.3: 1: 1.3 ; d 1: e 2: d 2-1: 1: 9 ; f 2$ : $h 2-1: 15$; ag1 : ag2 - $1.8: 1$. Hysteronotal shield entire, bearing bases setae $d 1$ and $e 2$. Two aggenital plates present, bearing bases of setae $a g 1$ on posterior margin.

Type material examined: Female holotype (non-physogastric form) and paratypes: one female (non-physogastric form), two females (physogastric form), one male, two nymphs from collared palm-thrush Cichladusa arquata (Passeriformes: Muscicapidae); Tanzania, Soga, 16 July 1960, coll. Th. Andersen. Type material is deposited in the ZSM (Reg. No. ZSM 20112002) and AMU (Reg. No. AMU-SYR.371).

Picobia dinemellia Glowska et Skoracki, 2011

Picobia dinemellia - Glowska and Skoracki 2011: 64, figs. 6-18.

This species has recently been described based on material found on ploceid host species, Dinemellia dinemelli (Ruppell) (Passeriformes: Ploceidae) in Tanzania (Glowska and Skoracki 2011).

\section{Diagnosis}

Female. Hypostomal apex rounded with shoulders. Each medial branch of peritremes with five chambers, each lateral branch with 9-10 chambers. Movable cheliceral digit edentate in posterior part. Propodonotal shield 
divided into two narrow lateral shields and small oval median fragment. All propodonotal setae lightly beaded. Length ratios of setae $v i: s i-1: 1.5 ; f 1: f 2-1: 1 ; h 1: f 1$ $-1: 2.7 ;$ agl : ag2 - 2: 1. Pygidial shield entire. Aggenital setae $a g 1$ situated anterior to level of setae $a g 2$. Setae gl short and thin, situated on genital lobes. Antaxial and paraxial members of claw pair of legs III and IV equal in size and shape.

Male. Hypostomal apex rounded. Each medial branch of peritremes with four chambers, each lateral branch with six chambers. Propodonotal shield entire. Setae ve situated anterior to setae $v i$. Length ratios of setae $v i$ : ve$1: 1.4 ; d 2: e 2-5.3: 1 ; f 2: h 2-1: 13 ;$ agl $:$ ag $2-4.3: 1$. Hysteronotal shield entire, bearing bases of setae $d 1$ and $e 2$. Two aggenital plates present, bearing bases of setae agl on posterior margin.

Type material examined: Female holotype, three physogastric female paratypes and one male paratype from white-headed buffalo-weaver Dinemellia dinemelli (Passeriformes: Ploceidae); Tanzania, no other data. All type material is deposited in the AMU (Reg. No. AMUSYR.426).

\section{Picobia echo Skoracki, Solarczyk et Sikora, 2012}

Picobia echo - Skoracki et al. 2012b: 126, figs. 10-21.

This species has recently been described based on material found on muscicapid bird species, Cossypha heuglini Hartlaub in Tanzania (Skoracki et al. 2012).

\section{Diagnosis}

Female. Hypostomal apex rounded, without shoulders. Each medial branch of peritremes with 4-5 chambers, each lateral branch with 6-8 chambers. Movable cheliceral digit edentate in posterior part. Podomers of palps densely punctate. Propodonotal shield divided into two narrow lateral and single oval median shields. Propodonotal setae lightly beaded. Length ratios of setae: $v i$ : ve : si- $1: 1: 1.4 ; f 1: h 1: f 2-1: 1: 2 ;$ agl : ag $2:$ ag $3-1.4$ $: 1: 2$. Pygidial shield entire. Aggenital setae $a g 1$ situated anterior to level of setae ag2. Genital plate present. Genital setae filiform, situated on genital lobes. Antaxial and paraxial members of claw pair of legs III and IV equal in size and shape.

Male. Hypostomal apex rounded. Each medial branch of peritremes with 3-4 chambers, each lateral branch with 7-8 chambers. Propodonotal shield divided into two narrow lateral and one unpaired oval shields. Bases of setae $v i$ and ve situated at same transverse level. Length ratios of setae $v i: v e: s i-1: 1: 1.1-1.2 ; d 2: d 1: e 2-7: 1$ : $1 ; h 2: f 2-13: 1$; agl : ag2 - 1.3-1.8: 1. Hysteronotal shield entire. Two aggenital plates present, situated close to each other, bearing bases of setae agl.

Type material examined: Female holotype (non-physogastric form) and paratypes: four females (physogastric form), two males, two nymphs and one larva from white- browed robin-chat Cossypha heuglini (Passeriformes: Muscicapidae); D. R. Congo, South Kivu Prov., Bukavu, 7 August 1969, coll. P. Kunkel. Type material is deposited in the ZSM (Reg. No. ZSM 20112010) and AMU (Reg. No. AMU-SYR.372).

\section{Picobia eremophila Skoracki, 2011}

Picobia eremophila see Skoracki 2011: 363, Figs. 272-274.

This species has recently been described based on material found on alaudid bird species Eremophila bilopha (Temminck) (Passeriformes: Alaudidae) in Egypt.

\section{Diagnosis}

Female. Hypostomal apex rounded, with shoulders. Each medial branch of peritremes with 2-3 chambers, each lateral branch with 6-8 chambers. Movable cheliceral digit dentate in posterior part. Propodonotal shield divided into two narrow lateral shields, medial shield absent. Setae $v i$ located slightly posterior to level of setae $v e$. Length ratios of setae $v i$ : ve : si-1.5-1.7 : $1: 1.9-2$; $f 1: f 2-1: 1.2 ; f 1: h 1-1: 5.4 ;$ agl : ag $2:$ ag3 -1 : $1: 1.2-1.5$. Propodonotal setae lightly beaded. Pygidial shield entire. Aggenital setae agl situated anterior to level of setae $a g 2$. Genital setae long and hair-like. Genital lobes absent. Antaxial and paraxial members of claw pair of legs III and IV equal in size and shape.

Male. Hypostomal apex with pair of minute, bluntended protuberances. Each medial branch of peritremes with three chambers, each lateral branch with eight chambers. Propodonotal shield entire, bearing bases of setae $v i$, $v e, s i$ and $s e$. Setae $v i$ situated posteriorly to level of setae $v e$. Length ratios of setae $v i: v e: s i-1.2: 1: 1.8 ; d 2: d 1$ $: e 2-3.8: 1: 1 ; a g 1: a g 2-1.3: 1$. Hysteronotal shield divided longitudinally, bearing bases of setae $d 1$ and $e 2$. Aggenital plate entire, bearing bases of setae $a g l$.

Type material examined: Female holotype and two female paratypes (physogastric forms) and one male paratype from Temminck's lark Eremophila bilopha (Passeriformes: Alaudidae): Egypt, no other data. Material is deposited in the AMU (Reg. No. AMU-SYR.273).

Picobia illadopsae sp. n.

Figs. 7-9

\section{Description}

Female (holotype and three paratypes, measurements of the latter in parentheses). Total body length 600 (555570). Gnathosoma. Infracapitulum sparsely punctate. Each medial branch of peritremes with eight chambers, each lateral branch with four striated chambers. Stylophore 170 (160) long. Idiosoma. Pair of narrow propodonotal shields sparsely punctate near bases of setae $v e$ and $s i$. Unpaired medial shield absent. Length ratio of setae $v i$ : ve : si-1 : $1: 1.3-1.5$. Bases of setae $v i$ situated slightly posterior to level of setae ve. Setae vi, ve and si lightly beaded. Setae se situated posterior to level of setae $c 1$. 

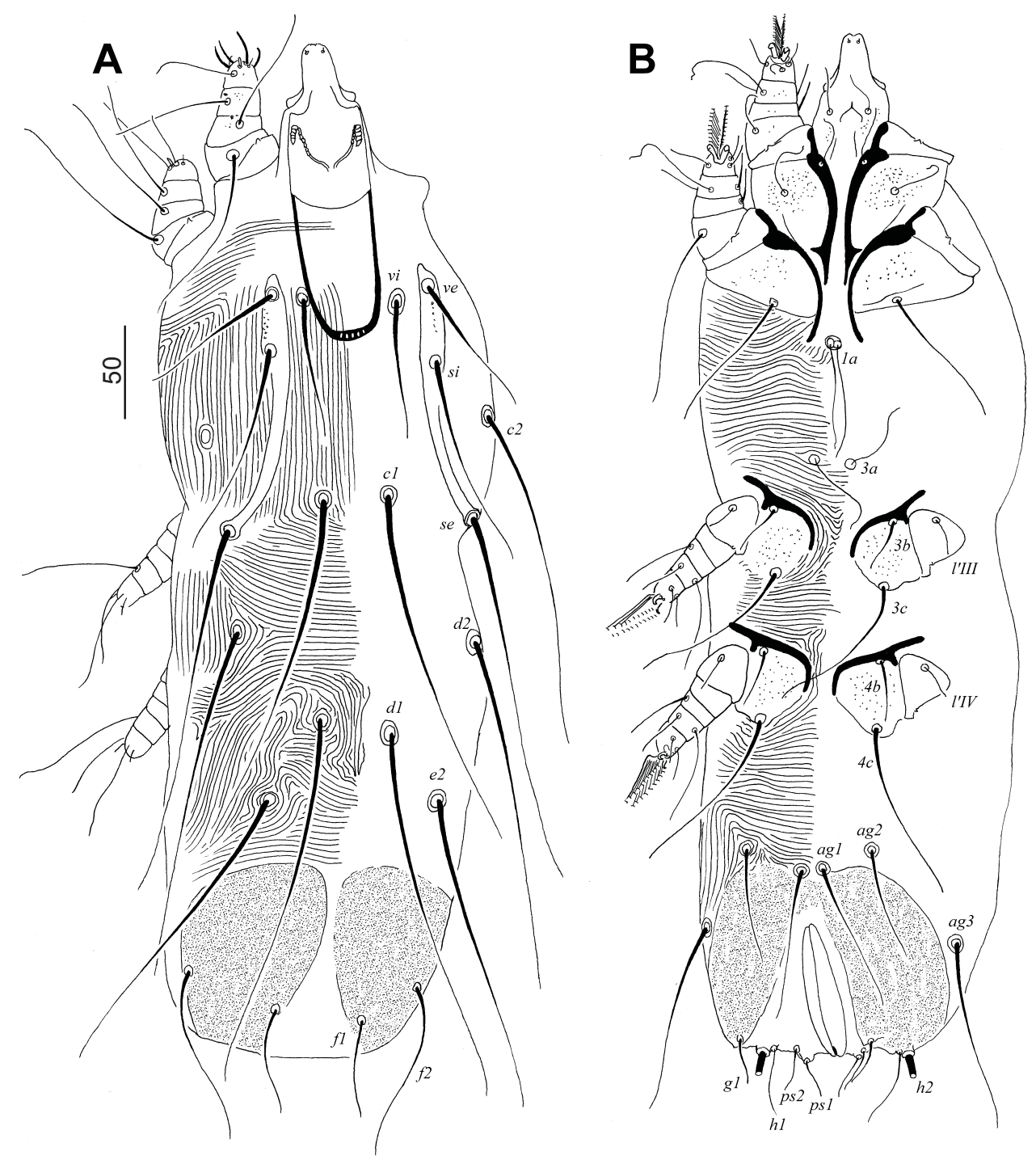

Fig. 7. Picobia illadopsae sp. n., female (Reg. No. AMU-SYR.427/1) from Illadopsis rufipennis. A - dorsal view; B - ventral view.

Hysteronotal shield absent. Pygidial shield well sclerotized covered by minute punctuations. Setae $f 11.4$ times longer than $h 1$. Setae $f 21.5-1.7$ times longer than $f 1$. Bases of aggenital setae $a g l$ situated near anterior margin of genital plate and slightly posterior to level of setae ag2. Length ratio of setae $a g 1:$ ag2 : ag3 1.4-1.5 : 1 : 1.5-1.8. Large genital plate covered by minute punctations. Setae ps 2 and $g 1$ subequal in length, both slightly shorter than ps 1. Genital setae $g 1$ situated on small genital lobes. All coxal fields well sclerotized and punctate. Setae $3 c$ about 3.0-3.4 times longer than 3b. Legs. Antaxial and paraxial members of claw pair of legs III and IV unequal in size and shape. Setae $t c$ "III-IV 1.3-1.5 times longer than tc'III-IV. Lengths of setae: vi 75 (75-80), ve 70 (75-80), si 115 (105), se 190 (180-190), c1 190 (175-185), c2 180 (170-180), d1 210 (190-200), d2 190 (180-190), e2 170 (160-185), f1 55 (50-65), f2 95 (95-100), h1 40 (40), h2 390, ag1 (85-90), ag2 65 (55-65), ag3 110 (100-110), ps1 35 (35), ps2 30 (25-30), g1 30 (25-30), tc'III-IV 40 (50-60), tc'III-IV 55 (65-70), l'RIII 20 (20), l'RIV 20 (20), 3b (25-30), 3c (85-90).

Physogastric female (five paratypes). Physogastric form vermiform outline.

Male (four paratypes). Total body length 425-440. Gnathosoma. Each medial branch of peritremes with seven chambers, each lateral branch with four striated chambers. Stylophore 100 long. Idiosoma. Pair of narrow propodonotal shields sparsely punctate near bases of setae $v e$ and $s i$; unpaired medial shield absent. Length ratio of setae $v i$ : ve : si-1:1:1.5-1.8. Bases of setae vi situated slightly posterior to level of setae $v e$. Setae $v i$, ve and si lightly beaded. Setae se situated posterior to level of setae $c 1$. Hysteronotal shield entire, with concave anterior margin, punctate laterally. Pygidial shield apunctate. Bases of aggenital setae agl situated at posterior margin of weakly sclerotized genital plate. Setae agl 2.6-2.7 

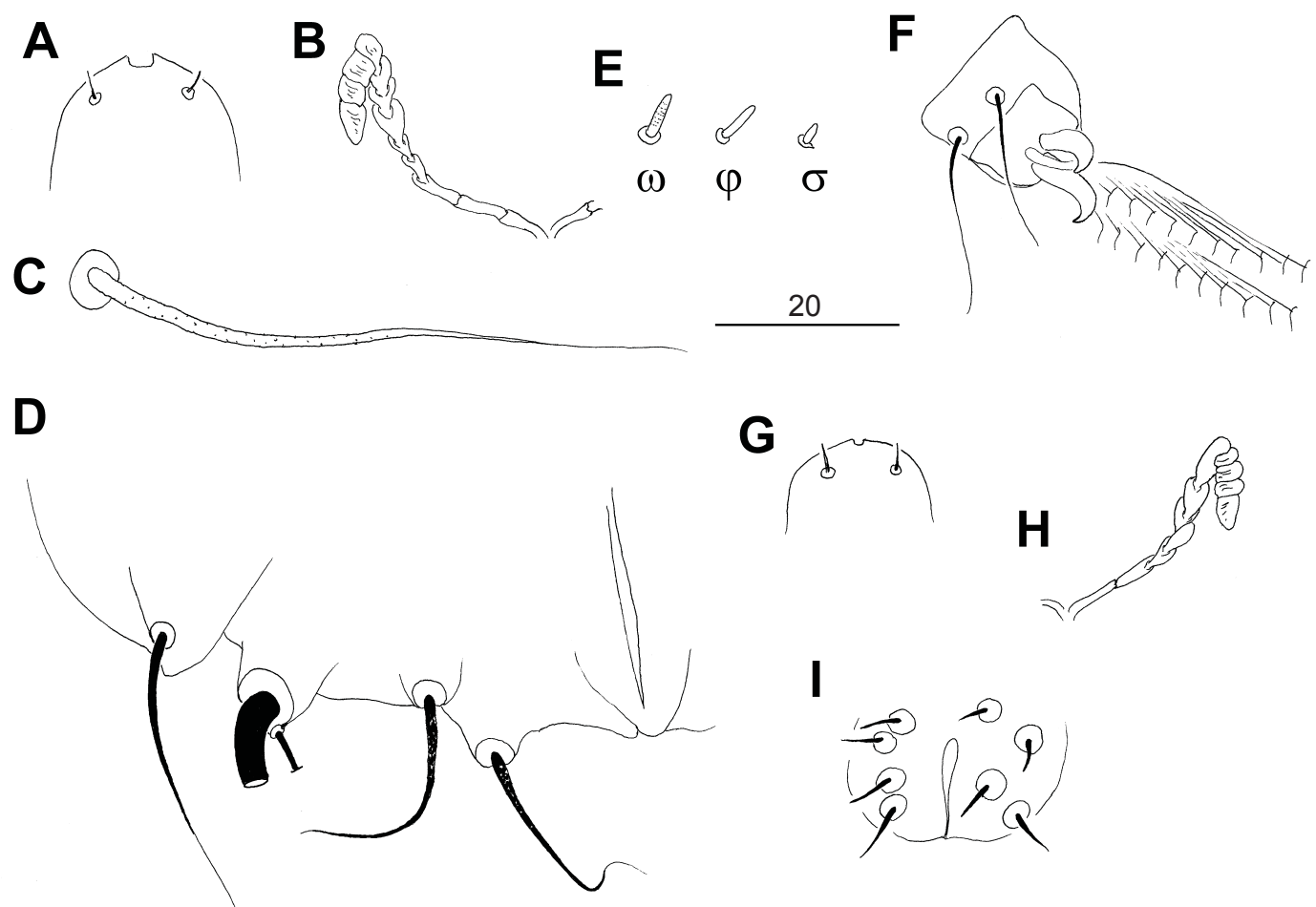

Fig. 8. Picobia illadopsae sp. n., female (Reg. No. AMU-SYR.427/1) from Illadopsis rufipennis (A-F). A - hypostomal apex; $\mathbf{B}$ - peritreme; $\mathbf{C}$ - propodonotal seta ve; $\mathbf{D}$ - genito-anal region; $\mathbf{E}$ - solenidia of leg I; $\mathbf{F}$ - tarsus III in ventrolateral view. Male (G-I) (Reg. No. AMU-SYR.427/6) from the same host species. $\mathbf{G}$ - hypostomal apex; H - peritreme; I - genito-anal region.

times longer than ag2. All coxal fields well sclerotized and punctate. Setae $3 c$ about twice as long as $3 b$. Lengths of setae: vi 45, ve 40-50, si 75, se 100-120, c1 140, c2 120-135, d1 15-20, d2 100-115, e2 15-20, f2 10-15, h2 200, ag1 40-60, ag2 15-25.

Type host: Pale-breasted illadopsis Illadopsis rufipennis (Sharpe) (Passeriformes: Pellorneidae).

L ocality: Kenya, Kakamega, Buyangu, Udo's Campsite, $0^{\circ} 21^{\prime} 11^{\prime \prime N}, 34^{\circ} 51^{\prime} 50 " \mathrm{E}, 1598 \mathrm{~m}$ a.s.1., 7 April 2011, coll. W. Wamiti.

Type material: Female holotype (non-physogastric form) and paratypes: three females (non-physogastric form), five females (physogastric form) and four males. All type material is deposited in the AMU (Reg. No. AMU-SYR.427/1-8) except one female (physogastric form) and one male in the IPCAS; one female (non-physogastric form), one female (physogastric form) and one male in ZISP (Reg. No. ZISP AVB011-2908-040).

Etymology: The specific epithet 'illadopsae' is adopted from the generic name of the host - Illadopsis.

Differential diagnosis. This new species is morphologically similar to $P$. cetti Skoracki, 2011 found on Cetti's warbler Cettia cetti (Temminck) (Passeriformes: Cettiidae) (Skoracki 2011). In females of both species, aggenital setae $a g 1$ and $a g 2$ are situated at the same transverse level; the genital lobes are well developed and bear genital setae; setae vi, ve and si are lightly beaded; the genital plate is densely punctate; the pygidial shield is divided longitudinally, antaxial and paraxial members of the claw pair of legs III and IV are unequal in size and not similar in shape. This new species differs from $P$. cetti by the following characters: in females of P. illadopsae, the propodonotal medial shield is absent; all coxal fields are densely punctate; each medial branch of the peritremes has eight chambers and the chambers in the lateral branches are distinctly striated. In females of $P$. cetti, the propodonotal medial shield is present; all coxal fields are apunctate; each medial branch of the peritremes has two chambers, and the chambers in the lateral branches are not striated.

Picobia myrmecocichla Skoracki, Solarczyk et Sikora, 2012

Picobia myrmecocichla - Skoracki et al. 2012b: 132, figs. 22-32.

This species has recently been described based on material found on muscicapid bird Myrmecocichla arnotti (Tristram) in Tanzania.

\section{Diagnosis}

Female. Gnathosoma. Hypostomal apex rounded, without shoulders. Movable cheliceral digit edentate posteriorly. Each medial branch of peritremes with 5-6 chambers; each lateral branch with seven chambers. Podomers of palps densely punctate. Propodonotal shield divided into two narrow lateral shields, median shield re- 

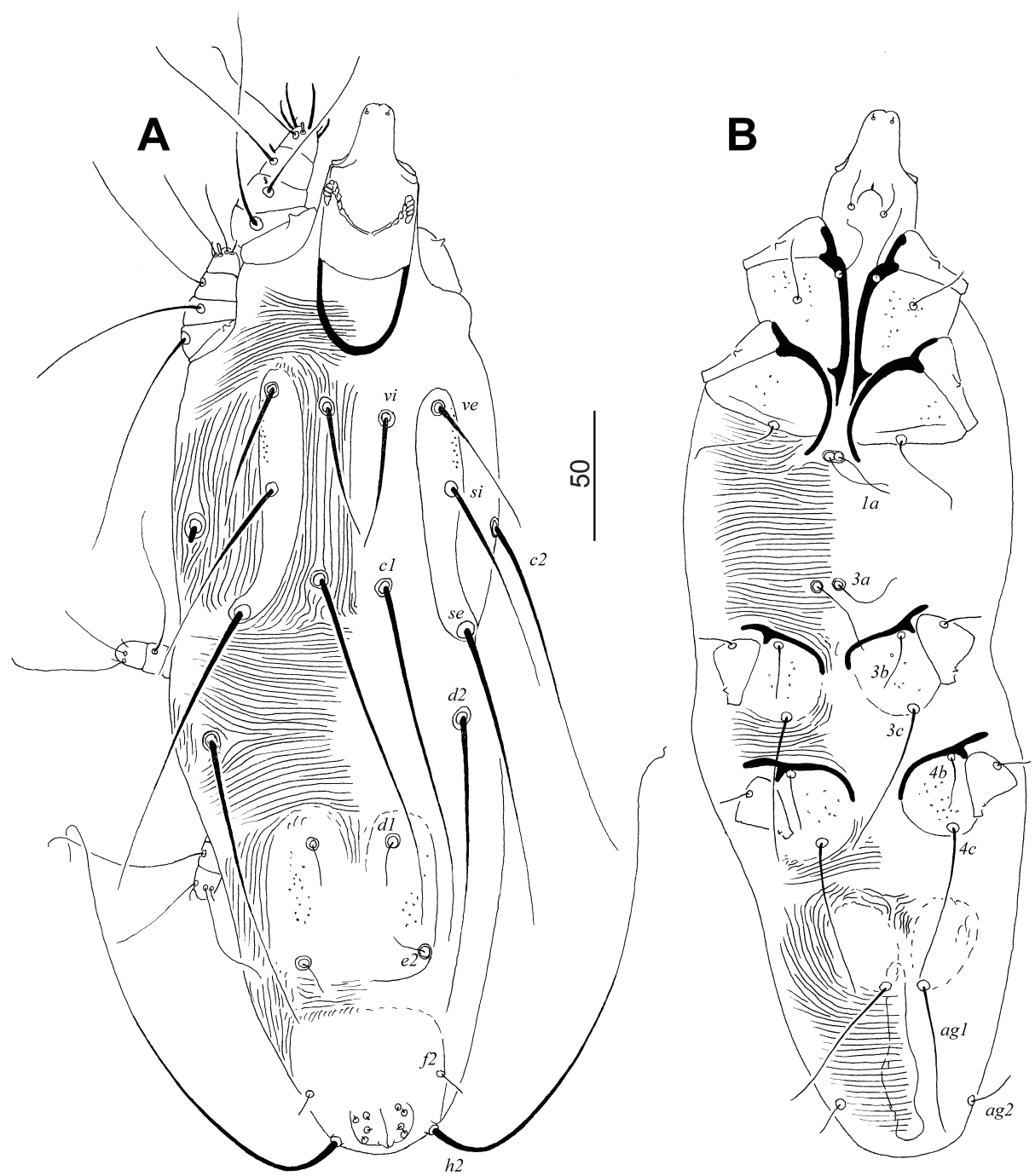

Fig. 9. Picobia illadopsae sp. n., male (Reg. No. AMU-SYR.427/6) from Illadopsis rufipennis. A - dorsal view; B - ventral view.

duced to small sclerite or absent. Length ratios of setae $v i$ :

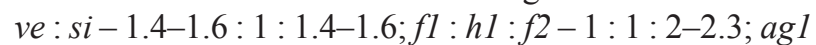
$: a g 2: \operatorname{ag} 3-2: 1: 2.7$. Bases of setae $v i$ situated slightly posterior to level of setae ve. Dorsal setae of idiosoma and legs lightly beaded. Pygidial shield entire. Aggenital setae ag1 situated anterior to level of setae ag2. Genital plate present. Genital setae filiform, situated on genital lobes. Antaxial and paraxial members of claw pair of legs III and IV equal in size and shape.

Male. Hypostomal apex rounded. Each medial branch of peritremes with three chambers, each lateral branch with 7-8 chambers. Propodonotal shield not divided, long-sleeved shirt-like. Length ratios of setae $v i: v e: s i-$ $1.2-1.3: 1: 1.4-1.5 ; d 2: d 1: e 2-8-10: 1: 1 ; f 2: h 2-1$ $: 15$; ag $1:$ ag $2-1: 1$. Propodonotal setae lightly beaded. Bases of setae $v i$ situated slightly posterior to level of setae ve. Hysteronotal shield entire. Two aggenital plates present, bases of setae agl situated near these plates.

Type material examined: Female holotype (non-physogastric form) and paratypes: one female (non-physogas- tric form), two females (physogastric form), two males, one nymph from white-headed black-chat Myrmecocichla arnotti (Passeriformes: Muscicapidae); Tanzania, 10 September 1963, coll. Th. Andersen. Type material is deposited in the ZSM (Reg. No. ZSM 20112011) and AMU (Reg. No. AMU-SYR.375).

Picobia oritis Skoracki, Antczak et Riegert, 2009

Picobia oritis - Skoracki et al. 2009: 133, figs. 15-25; Skoracki et al. 2011: 40.

This species was described based on material found on nectariniid host species, Cyanomitra oritis (Reichenow) (Passeriformes: Nectariinidae) in Cameroon (Skoracki et al. 2009). Later on, Skoracki et al. (2011) recorded this species on closely related host species, $C$. olivacea (Smith), in Kenya.

\section{Diagnosis}

Female. Hypostomal apex rounded, without shoulders. Each lateral branch of peritremes with three chambers, 


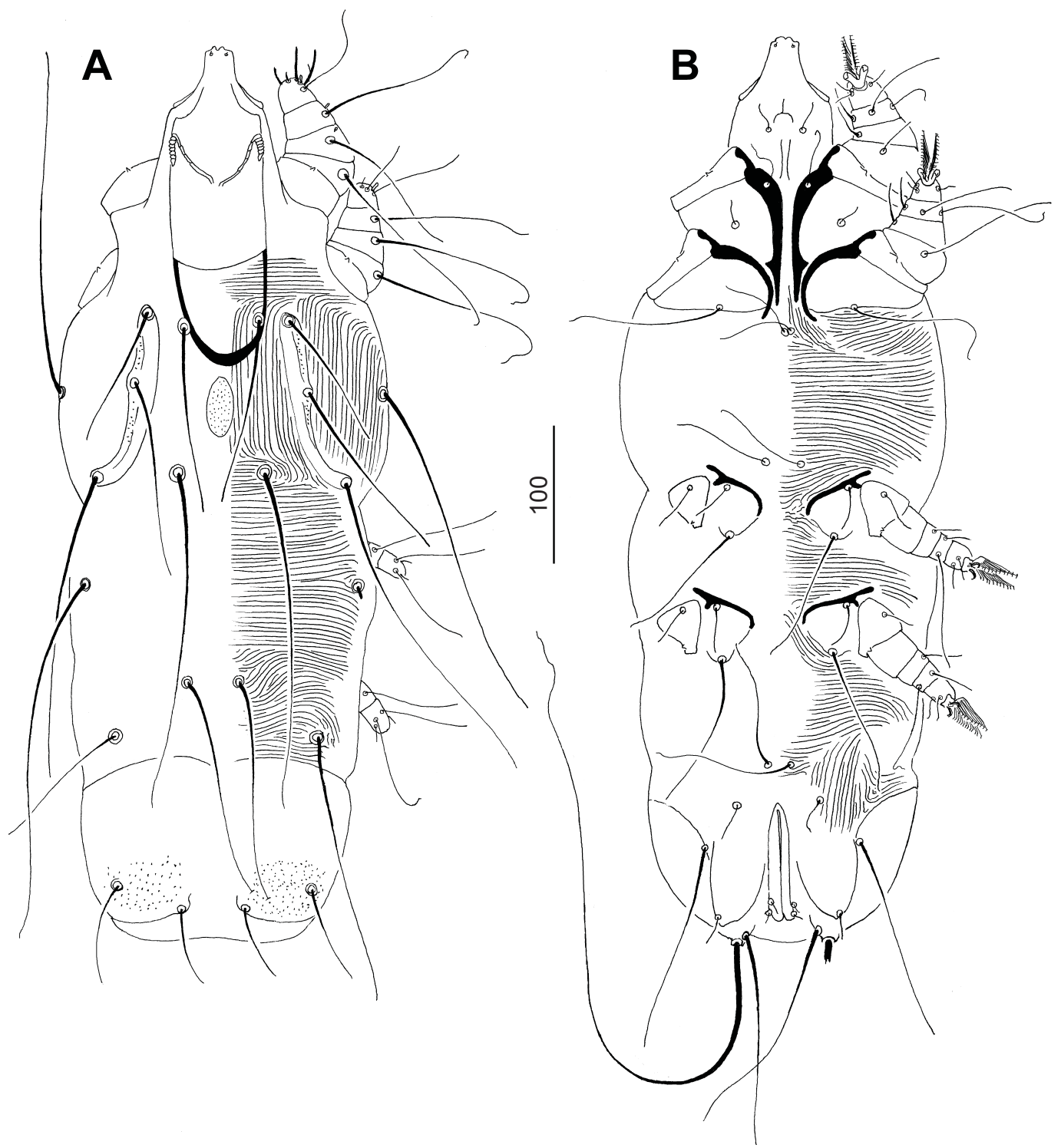

Fig. 10. Picobia phoeniculi Fain, Bochkov et Mironov, 2000, female from Phoeniculus purpureus. A - dorsal view; B - ventral view.

each longitudinal branch with seven chambers. Movable cheliceral digit with cuticular processes in posterior part. Propodonotal shield divided into two narrow shields, medial shield absent. Length ratios of setae $v i$ : ve : si-1: 1 : $1 ; f 1: f 2-1: 2$; ag1 : ag2 : ag3-1.1-1.3 : 1 : 1.6-2.2. Setae vi, ve and sci strongly beaded. Pygidial shield divided longitudinally. Bases of setae $a g 1$ and $a g 2$ situated at same transverse level. Genital setae filiform, situated on short genital lobes. Antaxial and paraxial members of claw pair of legs III and IV unequal in size and shape.

Male. Unknown.

Type material examined: Female holotype and four female paratypes (non-physogastric form) from Cameroon sunbird Cyanomitra oritis (Passeriformes: Nectariniidae); Cameroon, North-Western Province, Bamenda Highlands, Mendongbuo, $06^{\circ} 05^{\prime} \mathrm{N}, 10^{\circ} 18^{\prime} \mathrm{E}, 2200 \mathrm{~m}$ a.s.1.), coll. J. Riegert. Type material is deposited in the AMU (Reg.
No. AMU-SYR.228), ZISP (Reg. No. ZISP AVB0112908-004) and RMCA (Reg. No. RMCA 190394).

Additional material examined: Two females (physogastric form) from eastern olive sunbird Cyanomitra olivacea (Smith) (Nectariinidae); Kenya, Arabuko-Sokoke Forest, Gede, Tree House Nature Trail, $3^{\circ} 17^{\prime} \mathrm{S}, 39^{\circ} 55^{\prime} \mathrm{E}$, 39 m a.s.1., 16 December 2010, coll. M. Hromada and W. Wamiti. All material is deposited in the AMU (Reg. No. AMU-SYR.288).

\section{Picobia phoeniculi}

Fain, Bochkov et Mironov, 2000

Figs. 10-12

Picobia phoeniculi - Fain et al. 2000: 69, figs. 110-117; Skoracki et al. 2004: 168; Skoracki 2011: 328.

This species was described based on female material found on coraciiform bird species, Phoeniculus purpureus (Miller) (Coraciiformes: Phoeniculidae) in Rwanda (Fain 

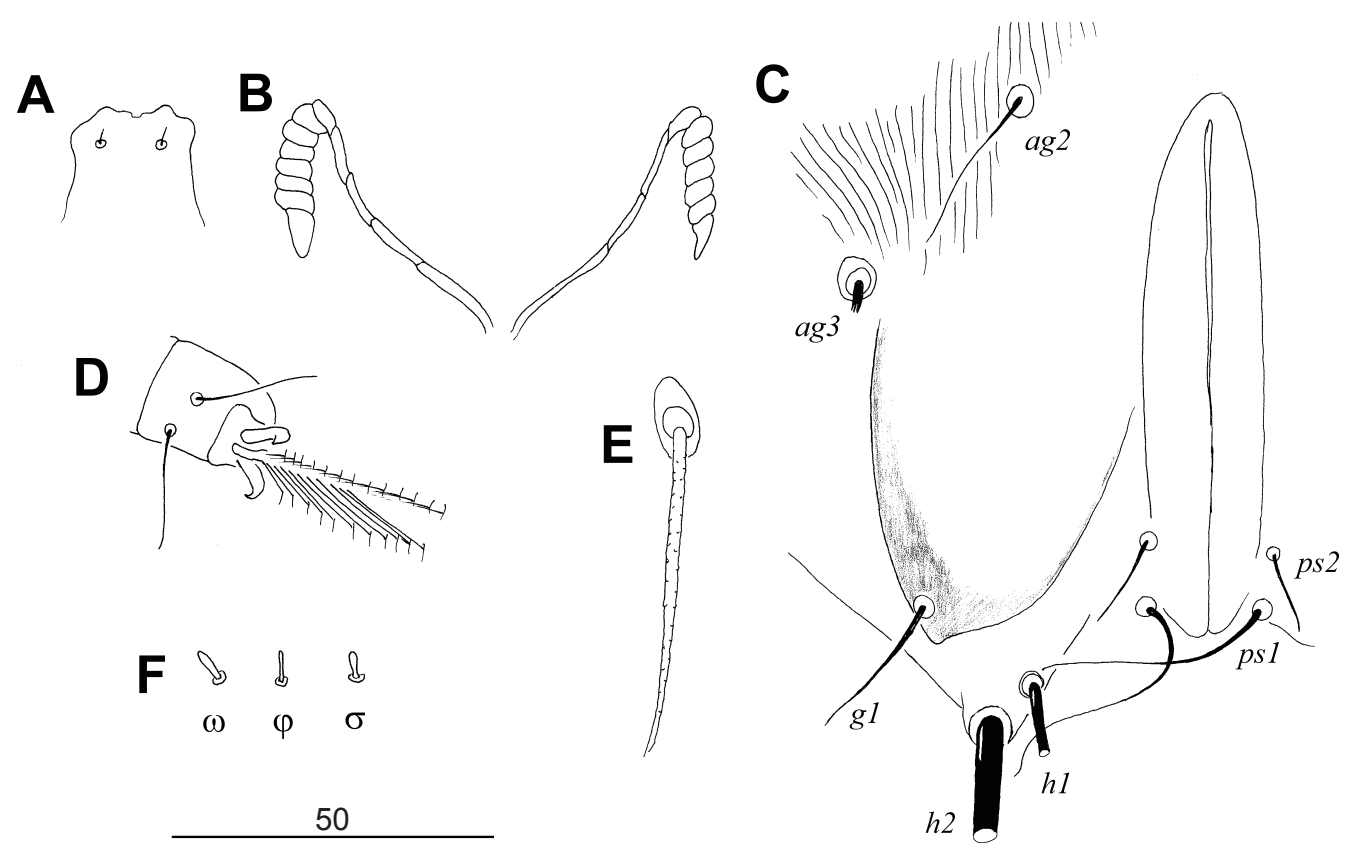

Fig. 11. Picobia phoeniculi Fain, Bochkov et Mironov, 2000, female from Phoeniculus purpureus. A-hypostomal apex; B - peritremes; $\mathbf{C}$ - genito-anal region; D - tarsus III in ventrolateral view; $\mathbf{E}$ - propodonotal seta ve; $\mathbf{F}$ - solenidia of leg I.

et al. 2000), and to this time there were no other data since the original description. Below, we give a redescription of this species based on the type material (females and males) deposited in the RBINS. Additionally, a new locality and new host record for P. phoeniculi are listed.

\section{Redescription}

Female (two paratypes). Total body length 645. Gnathosoma. Hypostomal apex rounded, with shoulders. Movable cheliceral digit edentate in posterior part. Each medial branch with five chambers, each lateral branch with 6-7 chambers. Stylophore 245 long. Idiosoma. Propodonotal shield divided into two narrow lateral and single median shield, all sclerites punctate. Length ratio of setae $v i$ : ve : si-1.4: $1: 1.4$. Setae $v i$ situated slightly posterior to level of setae ve. Setae vi, ve and si lightly beaded. Setae se and $c 1$ situated at same transverse level or setae $c 1$ located slightly anterior to level of setae se. Hysteronotal shield absent. Setae $d 2$ slightly (1.2 times) longer than $e 2$. Pygidial shield well developed, punctate, covered also ventral side. Setae $f 2$ 1.5-1.9 times longer than $f 1$. Setae $h 12.1-2.5$ times longer than $f 2$, and 3.0-4.5 times longer than $f 1$. Aggenital setae agl situated anterior to level of setae ag2. Length ratio of setae ag1 : ag2 : ag3 $-3.3: 1: 4.8$. Genital plate present, apunctate. Setae $p s 2$ 2.3-3.3 times longer than ps 1. Pair of short and filiform genital setae situated on genital lobes. All coxal fields well sclerotized, apunctate. Setae $4 c 3.3$ times longer than 4b. Legs. Antaxial and paraxial members of claw pair of legs III and IV equal in size and shape. Setae $t c$ ' and $t c$ ", of legs III and IV subequal in length. Lengths of setae: vi 140, ve 100, si 145, se 230-245, c1 280, c2 250, d2
260, e2 190-215,f1 35-55, f2 65-85, h1 160-175, h2 480, ag1 100, ag2 30, ag3 145-160, g1 20, ps1 15-20, ps2 50, tc'III-IV 65-70, tc'III-IV 70-75, l'RIII 35, l'RIV 30, 3b 30-35, 3c 100-115.

Physogastric female (one paratype). Body, vermiform outline, 1305 long.

Male (one paratypes). Total body length 535-580. Gnathosoma. Hypostomal apex flat. Stylophore 125-130 long. Each medial branch of peritremes with four chambers, each lateral branch with 8-9 chambers. Idiosoma. Propodonotal shield, divided into two narrow lateral shields and single oval shield median shield; all sclerites punctate. Length ratio of setae $v i$ : ve : si-1.1-1.2: 1 : 1.4-1.6. Bases of setae ve situated slightly anterior to level of $v i$. Setae $c l$ situated slightly anterior to level of setae se. Hysteronotal shield well developed, entire, apunctate, bearing bases of setae $d 1$ and $e 2$. Setae $d 2, c 1, c 2$ and se subequal in length, all about 11-14 times longer than $d 1$ and $e 2$. Setae $d 1$ situated closer to $e 2$ than to $d 2$. Pygidial shield apunctate. Aggenital plate entire, deeply concave on posterior margin, apunctate, bearing bases of setae $\mathrm{ag} 1$ on posterior margin. Setae ag1 3.7 times longer than ag2. All coxal fields well sclerotized, apunctate. Legs. Setae tc' $I I I-I V$ and $t c$ 'III-IV subequal in length. Lengths of setae: vi 95-105, ve 85, si 120-135, se 150-160, c1 150180, c2 150-160, d1 10-15, d2 155-170, e2 10-15, f2 10, h2 250-270, ag1 55, ag2 15, tc'III-IV and tc' III-IV 40, l'RIII and l'RIV 20, 3b 20, 3c 55.

Type material examined: Female holotype, two female paratypes (non-physogastric form), one female paratype (physogastric form) and two male paratypes from green woodhoopoe Phoeniculus purpureus (Coraciiformes: 


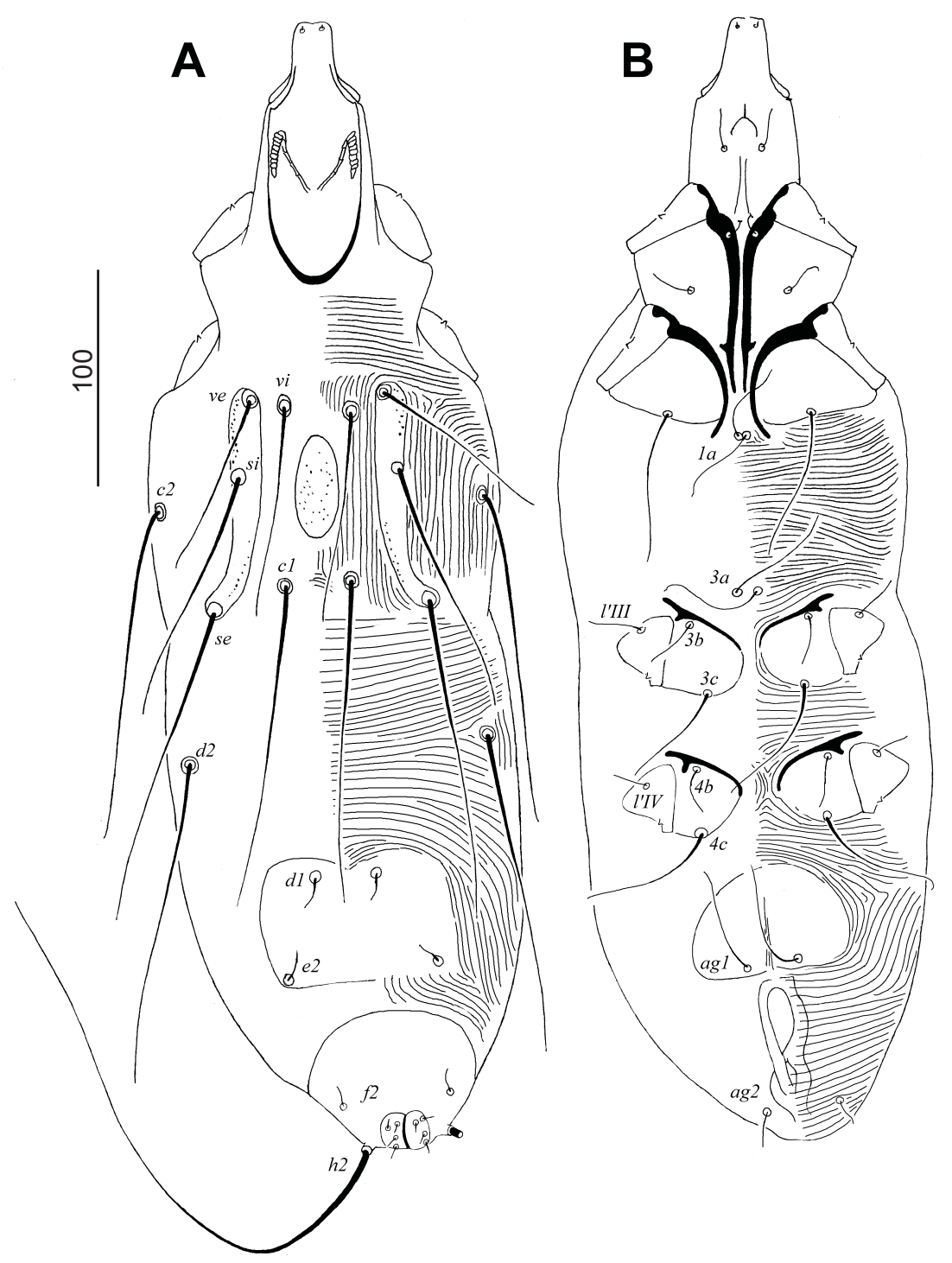

Fig. 12. Picobia phoeniculi Fain, Bochkov et Mironov, 2000, male from Phoeniculus purpureus. A - dorsal view; B - ventral view.

Phoeniculidae); Rwanda, December 1954, coll. A. Fain. All type material is deposited in the RBINS (Reg. No. RBINS 187374).

Additional material examined: One female (non-physogastric form), two females (physogastric form), one nymph from African subspecies of Eurasian hoopoe $U p$ upa epops africana Bechstein (Coraciiformes: Upupidae), Tanzania, Manyara, Iraku, July 1911, coll. Kattwinkel. Mite material is deposited in the AMU (Reg. No. AMUSYR.351B).

\section{Picobia phoenicuri sp. n.}

Figs. 13-15

\section{Description}

Female (holotype and one female paratype, physogastric form). Total body length 1095 . Gnathosoma. Infracapitulum apunctate. Each medial branch of peritremes with
4-5 chambers, each lateral branch with 8-9 chambers. Stylophore (160) long. Idiosoma. Pair of narrow propodonotal shields sparsely punctate near bases of setae ve and $s i$; unpaired medial shield oval in shape, punctate. Length ratio of setae $v i: v e: s i-1.3: 1: 1.4-1.6$. Bases of setae $v i$ and ve situated at same transverse level. Setae $v i$, ve and si lightly beaded. Setae $s e$ situated posterior to level of setae $c 1$. Hysteronotal shield absent. Pygidial shield well sclerotized covered by minute punctuations. Setae $f 1$ and $h 1$ subequal in length. Setae $f 2$ about twice as long as $f 1$. Bases of aggenital setae $a g l$ situated near anterior margin of genital plate and anterior to level of setae $a g 2$. Length ratio of setae $a g 1: a g 2: a g 3-1.6: 1: 2$. Large genital plate covered by minute punctations. Setae ps1 1.4-1.6 times longer than ps 2 and $g 1$. Genital setae situated on genital lobes. All coxal fields well sclerotized and apunctate. Setae $3 c$ about twice as long as $3 b$. Legs. Antaxial and paraxial members of claw pair of legs III 

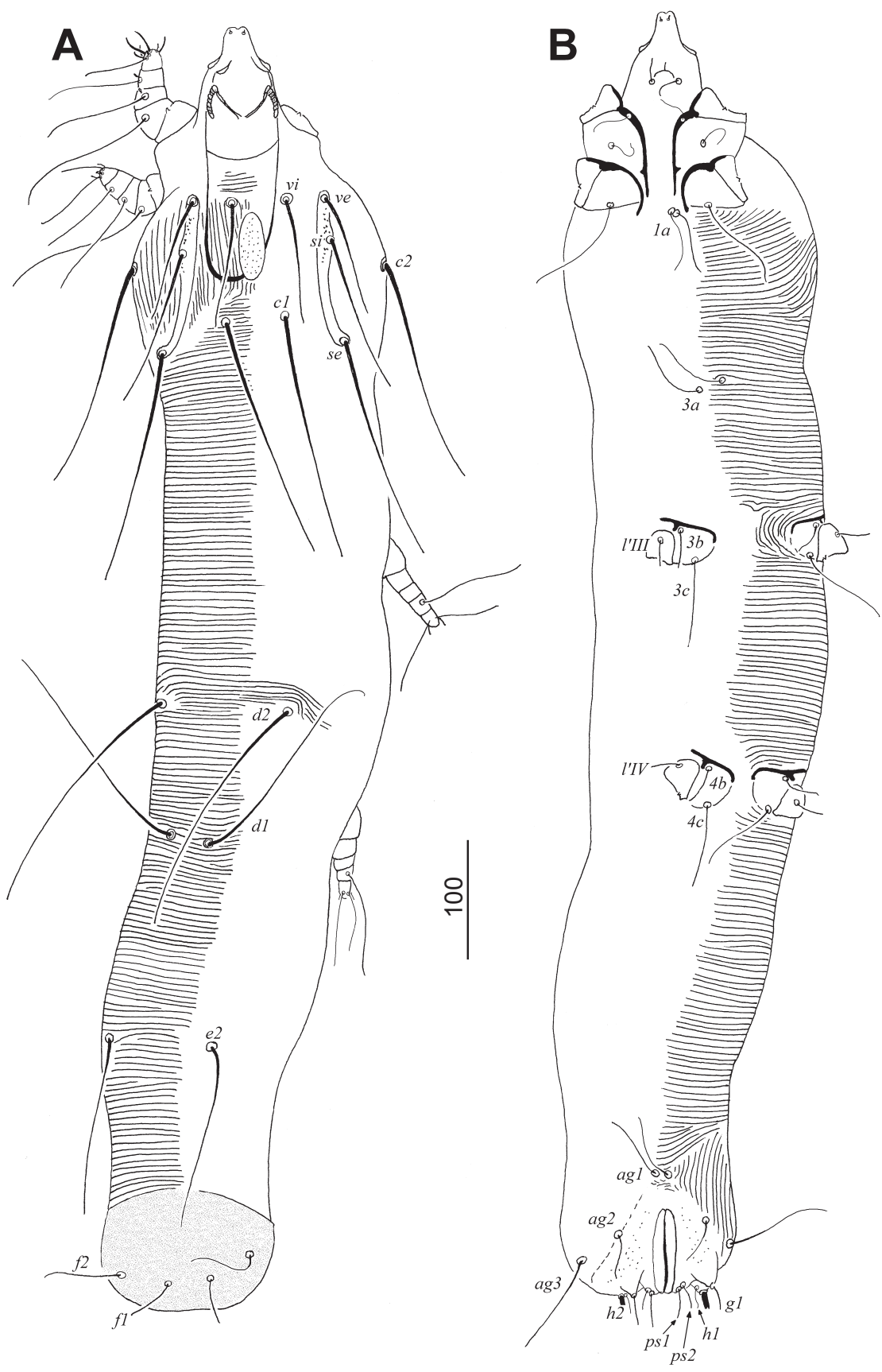

Fig. 13. Picobia phoenicuri sp. n., female (Reg. No. AMU-SYR.393/1) from Phoenicurus moussieri. A - dorsal view; B - ventral view.

and IV equal in size and shape. Setae $t c " I I I-I V$ slightly (1.2 times) longer than $t c^{\prime} I I I-I V$ or both pairs subequal in length. Lengths of setae: vi 115 (125), ve 90 (100), si 140 (140), se 205 (195), cl 205 (205), c2 190 (190), d1 190 (180), d2 220 (200), e2 $150(145), f 135(30), f 265(60)$, h1 30 (30), h2 300 (295), ag1 65 (65), ag2 (40), ag3 85 (85), ps 140 (35), ps2 25 (25), g1 25 (25), tc'III-IV 40 (50-60), tc"III-IV 55 (65-70), l'RIII 20 (20), l'RIV 20 (20), $3 b 30$ (35), 3c 60 (70).

Male (two paratypes). Total body length 425-435. Gnathosoma. Each medial branch of peritremes with four chambers, each lateral branch with 6-7 chambers. Stylophore 105 long. Idiosoma. Pair of narrow propodonotal shields sparsely punctate near bases of setae ve and si. Unpaired medial shield present. Length ratio of setae $v i: v e: s i-1: 1: 1$. Bases of setae $v i$ and ve located at same transverse level. Setae $v i$, ve and si lightly beaded. Setae se situated posterior to level of setae $c 1$. Hysteronotal shield entire, apunctate. Pygidial shield apunctate. Bases of aggenital setae $a g 1$ situated at posterior margin of entire and well sclerotized aggenital plate. Setae $a g 1$ 1.6 times longer than $a g 2$. All coxal fields well sclero- 


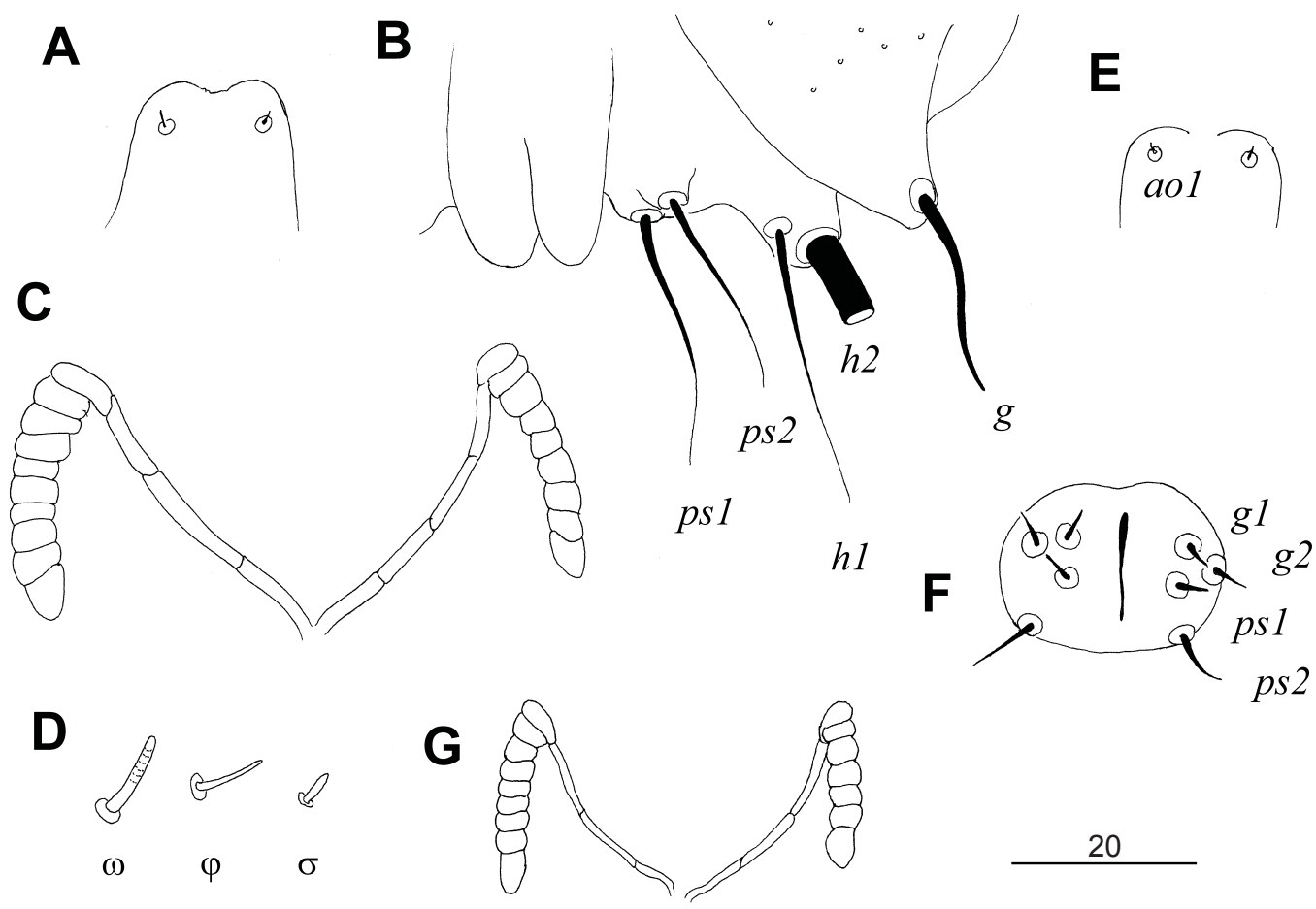

Fig. 14. Picobia phoenicuri sp. n., female (A-D) (Reg. No. AMU-SYR.393/1) from Phoenicurus moussieri. A - hypostomal apex; B - genito-anal region; C - peritremes; D - solenidia of leg I. Male (E-G) (Reg. No. AMU-SYR.393/3). E - hypostomal apex; $\mathbf{F}$ - genito-anal region; $\mathbf{G}$ - peritremes.

tized and apunctate. Setae $3 c$ about twice as long as $3 b$. Lengths of setae: vi 70-75, ve 70-75, si 75, se 110-130, cl 130-140, c2 105-120, d1 15, d2 120-125, e2 15, f2 10, h2 145-155, ag1 40, ag2 25.

Type host: Moussier's redstart Phoenicurus moussieri (Olphe-Galliard) (Passeriformes: Muscicapidae).

L o c a lity: Tunisia, coll. Blanc, no other data.

Type material: Female holotype (physogastric form), one female paratype (physogastric form) and two male paratypes. All material is deposited in the AMU (Reg. No. AMUSYR.393/1-4).

Ety mology: The name of this new species refers to the generic name of the host - Phoenicurus.

Differential diagnosis. This new species is morphologically very similar to $P$. echo Skoracki, Solarczyk et Sikora, 2012 found on white-browed robin chat, Cossypha heuglini Hartlaub (Passeriformes: Muscicapidae) (Skoracki et al. 2012b). In both species most qualitative characters are similar. Mites of these two species can be distinguished by measurements of setae. In females of P. phoenicuri sp. n., the lengths of setae si, c1, e2 and $f 2$ are $140,205-210,145-150$ and 60 , respectively; in males the lengths of setae ve, si, $c 2$ and $d 2$ are 55-70, 75, 105-120 and 120-125, respectively. In females of $P$. echo, the lengths of setae $s i, c 1, e 2$ and $f 2$ are 180,240,185, and 90 respectively; in males the lengths of setae ve, si, $c 2$ and $d 2$ are $100-115,100-125,150-160$ and 140 , respectively.

\section{Key to the genera of the Picobiinae (females)}

1 Opisthosomal lobes present. Movable cheliceral digit dentate, each with three teeth

Calamincola Casto, 1978

- Opisthosomal lobes absent. Movable cheliceral digit edentate 2

2 Solenidion $\varphi \mathrm{I}$ present 3

- Solenidion $\varphi \mathrm{I}$ absent ................................................ 7

3 Genital setae present ............................................. 4

- Genital setae absent .............. Gunabopicobia gen. n.

4 Bases of setae $1 a-1 a$ coalesced. Propodonotal shield divided into two or three separated sclerites .......... 5

- Bases of setae 1a-1a not coalesced. Propodonotal shield entire Lawrencipicobia gen. n.

5 Setae $v i$ and ve situated in transverse row. Lateral propodonotal shields bearing bases of setae ve, si and se. Apodemes I with thorn-like projection in middle part ..

- Setae vi and ve situated in longitudinal row. Lateral propodonotal shields bearing bases of setae vi, ve, si and se. Apodemes I without thorn-like projection in middle part

Columbiphilus Kivganov et Sharafat, 1995 

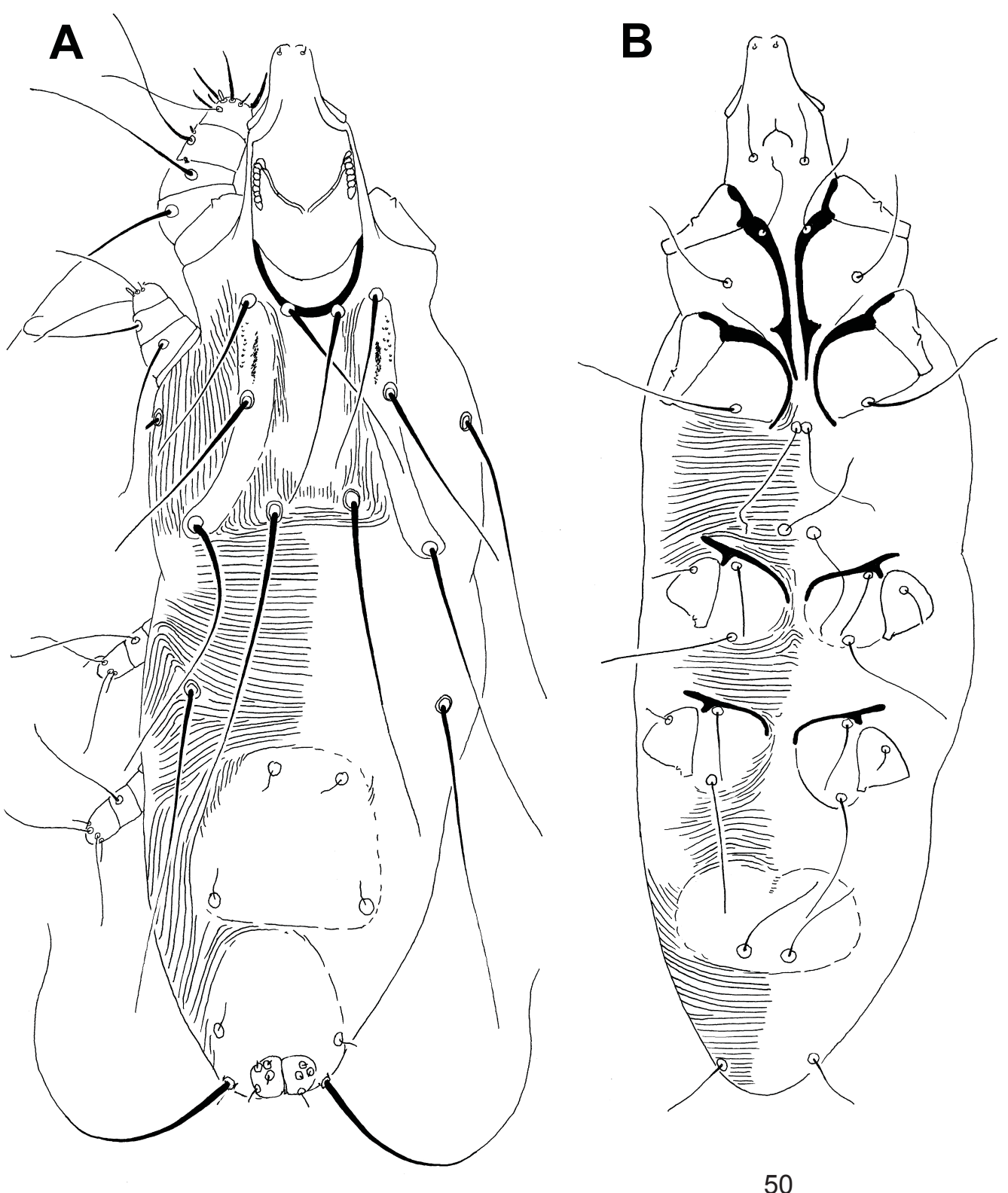

Fig. 15. Picobia phoenicuri sp. n., male (Reg. No. AMU-SYR.393/3) from Phoenicurus moussieri. A - dorsal view; B - ventral view.

6 Genital setae absent. Genital lobes are absent. Solenidion $\varphi \mathrm{I}$ represented by microseta, solenidion $\sigma \mathrm{I}$ setiform

Pseudopicobia Skoracki, Scibek et Sikora, 2012

- Genital setae present. Genital lobes present. Solenidion $\varphi \mathrm{I}$ distinctly developed, solenidion $\sigma \mathrm{I}$ bulb-like ... Picobia Haller, 1878

7 One pair of genital setae and two pairs of pseudanal setae present Rafapicobia Skoracki, 2011

- Genital setae absent, two pairs of pseudanal setae present Neopicobia Skoracki, 2011
Acknowledgements. We would like to thank Prof. Gerhard Haszprunar (Director of ZSM) and Dr. Markus Unsoeld (Leader of ornithological section in the ZSM) for making available samples of dry bird skins for the present study, Wanyoike Wamiti (Department of Entomology, National Museum of Kenya, Nairobi) for providing us with his field mite samples and Barry Nattress (Tingley, Wakefield, West Yorkshire, England) for critical review of the manuscript. This work was financially supported by the Polish Committee for Scientific Research (Grant No. NN 303802540). Additionally, MS was financially supported by the institutional grant FHNS of University of Prešov, and by the SYNTHESYS Project (http://www.synthesys.info/), which was funded by the European Community Research Infrastructure Action under FP7 (BE-TAF-1687), MH was supported by VEGA 1/1244/12 and OPVaV ITMS 26110230069. 
Bochkov A.V., Mironov S.V. 1998: Quill mites of the family Syringophilidae Lavoipierre, 1953 (Acariformes: Prostigmata) parasitic on birds (Aves) of the fauna of the former USSR. Acarina 6: 3-16.

Bochkov A.V., Mironov S.V., Kravtsova N.T. 2000: Two new syringophilid mites (Acari: Syringophilidae) from the Greenfinch Carduelis chloris (Passeriformes: Fringillidae) from Kirghizia. Genus 11: 351-358.

Bochkov A.V., Williams G., Proctor H. 2005: First record of Picobia zumpti (Acari: Syringophilidae) from quills of the rock pigeon in North America and description of the male. Belg. J. Entomol. 7: 121-127.

CASTO S.D. 1977: Cuculiphilus lobatus gen. n., sp. n. representing a new subfamily of quill mites (Acarina: Syringophilidae) from the groove-billed ani, Crotophaga sulcirostris (Cuculiformes: Cuculidae). Southwest. Natur. 22: 169-176.

Clements J.F., Schulenberg T.S., Iliff M.J., Sullivan B.L., Wood C.L. Roberson D. 2012: The eBird/Clements checklist of birds of the world: Version 6.7. The Cornell Lab Ornithology, Ithaca, New York, www.birds.cornell.edu/clementschecklist/ downloadable-clements-checklist, 01/2013.

Fain A., Bochkov A.V., Mironov S.V. 2000: New genera and species of quill mites of the family Syringophilidae (Acari: Prostigmata). Bull. Inst. Roy. Sci. Nat. Belg. 70: 33-70.

Glowska E., Dragun-Damian A., Dabert J. 2012: Picobia dziabaszewskii sp. nov. (Acari, Syringophilidae) - combined description (morphology with DNA barcode data) of a new quill mite species parasitizing Garrulax formosus (Passeriformes: Leiothrichidae). Zootaxa 3224: 57-61.

Glowska E., Skoracki M. 2011: Two new quill mite species (Acari, Cheyletoidea, Syringophilidae) parasitizing Dinemellia dinemelli (Rüppell) (Passeriformes, Ploceidae). Zootaxa 3114: 63-68.

Glowska E., Skoracki M., Khourly F. 2007: A new species and new records of syringophilid mites (Acari: Prostigmata: Syringophilidae) from birds of Jordan. Zootaxa 1635: 63-68.

Grandjean F. 1939: Les segments postlarvaires de l'hysterosoma chez les oribates (Acariens). Bull. Soc. Zool. (France) 64: 273 284.

Grandjean F. 1944: Observations sur les acariens de la famille des Stigmaeidae. Arch. Sci. Phys. Nat. 26: 103-131.

Kethley J.B. 1970: A revision of the family Syringophilidae (Prostigmata: Acarina). Contr. Amer. Entomol. Inst. 6: 1-76.

Kethley J.B. 1990: Acarina: Prostigmata (Actinedida). In: D.L. Dindal (Ed.), Soil Biology Guide. Wiley and Sons, New York, pp. 667-754.

Kivganov D.A., Sharafat G.S. 1995: [Review of the family Syringophilidae (Acari) with the description of new genera and species]. Zool. Zh. 74: 82-91. (In Russian.)

Lawrence R.F. 1959: New mites parasites of African birds (Myobiidae, Cheyletidae). Parasitology 49: 416-438.

Sikora B., Fajfer M., Kavetska K., Skoracki M. 2012: Three new species of quill mites (Acari: Syringophilidae) parasitizing the wrens (Aves: Troglodytidae). Zootaxa 3167: 57-65.

Sikora B., Fajfer M., Skoracki M. 2011: Quill mites (Acari: Syringophilidae) from mimid birds (Aves: Mimidae). Zootaxa 3027: 29-38.

SKORACKi M. 2011: Quill mites (Acari: Syringophilidae) of the Palaearctic region. Zootaxa 2840: 1-415.
Skoracki M., Antczak M., Riegert J., Fainova D., Mikes V. 2009: New species and new records of quill mites (Acari: Syringophilidae) inhabiting African passerines (Aves: Passeriformes). Acta Zool. Acad. Sci. Hung. 55: 123-137.

Skoracki M., Bochkov A.V., Wauthy G. 2004: Revision of the quill mites of the genus Picobia Haller, 1878 (Acari: Syringophilidae) with notes on their host-parasite relationships. Insect Syst. Evol. 35: 155-176.

Skoracki M., Dabert J. 2002: A review of parasitic mites of the family Syringophilidae (Acari, Prostigmata) from African birds, with descriptions of four new species. Acta Parasitol. 47: $137-146$.

Skoracki M., Glowska E. 2008: Two new species of the genus Picobia Haller (Acari: Syringophilidae) from Australian and Indonesian passeriform birds. New Zeal. J. Zool. 35: 281-286.

Skoracki M., Glowska E., Sikora B. 2008: Four new species of the quill mite genus Picobia Haller (Acari: Syringophilidae) parasitizing birds in the Australian region. Zootaxa 1961: $58-68$.

Skoracki M., Hebda G. 2004: Quill mites (Acari: Syringophilidae) from Aegithalos caudatus (Passeriformes: Aegithalidae). Zootaxa 691: 1-6.

Skoracki M., Hendricks S.A., Spicer G.S. 2010: New species of parasitic quill mites of the genus Picobia (Acari: Syringophilidae: Picobiinae) from North American birds. J. Med. Entomol. 47: 727-742.

Skoracki M., Hromada M., Wamiti W. 2011: A new species and new host records of syringophilid mites (Acari: Syringophilidae) from passerines from Kenya. Zootaxa 2922: 34-40.

Skoracki M., Kiljan G. 2002: Picobia paludicola sp. n. a new species of quill mite (Acari: Prostigmata: Syringophilidae) from the aquatic warbler Acrocephalus paludicola (Passeriformes: Sylviidae). Zootaxa 91: 1-6.

Skoracki M., Magowski W. 2001: Two new species of quill mites of the genus Picobia (Acari: Prostigmata: Syringophilidae) from passerine birds of Poland. Acarina 9: 113-119.

Skoracki M., Magowski W., Dabert J. 2001: Picobia polonica sp. n. (Acari: Prostigmata: Syringophilidae), a new species of quill mite from the domestic hen, Gallus gallus domesticus (Aves: Phasianidae). Folia Parasitol. 48: 154-158.

Skoracki M., O'Connor B. 2010: New taxa of quill mites (Acari: Cheyletoidea: Syringophilidae). Zootaxa 2341: 1-32.

Skoracki M., Scibek K., Sikora B. 2012a: New genus and three new species of quill mites (Acari: Syringophilidae: Picobiinae) parasitising puffbirds (Aves: Piciformes). Folia Parasitol. 59: 229-236.

Skoracki M., Sikora B. 2011: Quill mites (Acari: Syringophilidae) associated with galliform birds (Aves: Galliformes). Zootaxa 2966: 13-30.

Skoracki M., Solarczyk P. 2012: New picobiine mites (Acari: Syringophilidae: Picobiinae) associated with woodcreeper birds (Passeriformes: Dendrocolaptidae). Zootaxa 3406: 59-66.

Skoracki M., Solarczyk P., Sikora B. 2012b: Three new species of picobiine mites (Acari: Syringophilidae) parasitising African flycatchers (Aves: Muscicapidae). Syst. Parasitol. 83: $123-135$.

Skoracki M., Zabludovskaya S., Bochkov A.V. 2012c: A review of Prostigmata (Acariformes: Trombidiformes) permanently associated with birds. Acarina 20: 67-107. 